\author{
Dr. sc. Mato Arlović \\ sudac Ustavnog suda Republike Hrvatske
}

\title{
POZITIVNA DISKRIMINACIJA U REGULACIJI I ZAŠTITI PRAVA I SLOBODA PRIPADNIKA NACIONALNIH MANJINA - ULOGA USTAVNOG SUDA REPUBLIKE HRVATSKE
}

\author{
UDK: $342.7(497.5)$
}

DOI: $10.31141 /$ zrpfs.2019.56.134.785

Izvorni znanstveni rad

Primljeno: 15. VIII. 2019.

Provedba načela zabrane diskriminacije jedna je od najvažnijih zadaća svih tijela koja se bave zaštitom ljudskih prava i temeljnih sloboda. Naime, svaka realizirana zabranjena diskriminacija čvrsti je pokazatelj povrede ljudskih prava i temeljnih sloboda. Međutim, i od tog bitnog načela u pravnopolitičkim i ukupnim društvenim odnosima postoje iznimke odnosno odstupanja. Ona se očituju u načelu pozitivne diskriminacije koja je nužni korektiv u ostvarivanju prava i slobode manjina (podzastupljenih skupina) i njihovih pripadnika. Naime, u demokratskim društvima u kojima načelo većine dominira u donošenju odluka podzastupljene skupine stalno ovise o odlukama koje donosi većina. Bez obzira na to koliko je većina "demokratska", demokratsko društvo vladavine prava ne može pustiti na slobodnu procjenu većini hoće li odlučiti kod pravnog uređivanja, ostvarivanja i zaštite manjinskih prava tako da im omogući njihovu realizaciju u svim segmentima društvenih odnosa bitnih prava i sloboda za njihovu samoaktualizaciju. Zbog toga se u pravnim državama putem pravnog uređivanja pozitivne diskriminacije osigurava ustavnopravno jamstvo manjinama i njihovim pripadnicima na uređivanje, ostvarivanje i zaštitu tzv. pozitivnih prava i sloboda koja im jamče samoaktualizaciju kroz ostvarenje svojeg ethosa. Pozitivna diskriminacija upravo stoga jedno je od najsloženijih i vrlo osjetljivih pravnopolitičkih pitanja uopće. Ona je potrebna. Doduše jest pozitivna, ali istodobno je i diskriminacija. Njezina osjetljivost prisutna je, neovisno o osnovama za koje se propisuje. No, u odnosu na neke od njih, može imati, a najčešće i ima i šire političkopravne pa uopće i kulturološke implikacije. Eklatantan je primjer primjena načela pozitivne diskriminacije kod nacionalnih manjina i njihovih pripadnika. Zbog te svoje osjetljivosti svaka pozitivna diskriminacija, da bi bila dopuštena i opravdana, mora biti nužna i potrebna u demokratskom društvu, objektivno opravdana s unaprijed pravom utvrđenim legitimnim ciljem i njemu razmjerna.

U ovom radu nastojao sam se pojmovno odrediti prema pojmovima zabrane i pozitivne diskriminacije i njihovu međusobnom razlikovanju. Obradio sam najznačajnije, po mom sudu, pravne izvore koji uređuju ta načela kako nadnacionalnog tako i nacionalnog prava.

Posebnu sam pozornost posvetio pozitivnoj diskriminaciji u uređivanju, ostvarivanju i zaštiti prava i sloboda nacionalnih manjina i njihovih pripadnika. Naravno, unutar ustavnopravnog poretka Republike Hrvatske.

$\mathrm{Na}$ kraju rada pozabavio sam se ustavnosudskim postupanjima i odlučivanjima Ustavnoga suda Republike Hrvatske u apstraktnoj i konkretnoj kontroli ustavnosti i zakonitosti pozitivnih diskriminacija u odnosu na nacionalne manjine i njihove pripadnike. Zauzeta stajališta Ustavnoga suda u postupanjima u ovakvim predmetima potvrdio sam konkretnim primjerima na kraju rada. 
Dr. sc. Mato Arlović: Pozitivna diskriminacija u regulaciji i zaštiti prava i sloboda pripadnika... Zbornik radova Pravnog fakulteta u Splitu, god. 56, 4/2019, str. 785-815

Ključne riječi: ljudska (i manjinska) prava, prava i temeljne slobode, zabrana diskriminacije, pozitivna diskriminacija, nacionalne manjine i njihovi pripadnici, ustavnost $i$ zakonitost, Ustavni sud Republike Hrvatske

\section{UVOD}

Zbog svoga značaja društvene vrednote, pravno uređivanje, ostvarivanje ljudskih prava i temeljnih sloboda danas je jedno od najzahtjevnijih i najsloženijih pitanja međunarodne zajednice. ${ }^{1}$ Pogotovo ako se sagledava i proučava u cjelini svoga sadržaja i obuhvata, kada po naravi stvari obuhvaća prava i slobode i pripadnika nacionalnih (i drugih) manjina, zatim² prava i slobode svakog ljudskog bića za slučaj izvanrednih stanja, a osobito onih koja su rezultat ratova, prirodnih katastrofa, epidemija itd. Danas ${ }^{3}$ su ljudska prava i temeljne slobode, njihovo ostvarivanje i zaštita prihvaćeni kao kulturološka osnova i vrednote demokratskog civiliziranog svijeta koje nužno proizlaze iz sveukupnosti njegova zajedničkog općehumanog naslijeđa utemeljenog na idealima i vrednotama slobode, jednakosti i ravnopravnosti u demokratskim društvima vladavine prava, ustavne i nacionalne demokracije. ${ }^{4}$ Slijedom toga, ona su kao predmet postala jedan od bitnih sadržajnih elemenata ustavne regulacije i ustavom primijenjene konstitucionalizacije pojedinih modernih demokratskih država, ali je istovremeno općeprihvaćena vrednota kao rezultat humanog nastojanja kroz povijest ljudskoga roda, jedan od ugaonih kamenova ljudskog zajedničkog povIjesnog (dobrog) naslijeđa i predmetom pravne regulacije na nadnacionalnoj razini (pravnim normama univerzalnog i regionalnog sustava).

Pravno uređivanje (po sadržaju i svom obuhvatu), ostvarivanje i zaštita (ljudskih i manjinskih) prava u svom formalnom i funkcionalnom obliku očitovanja jedan su od egzaktnih pokazatelja kojim se utvrđuje demokratičnost nekog društva, ostvarivanje vladavine prava u njemu te mogućnost formalnog i stvarnog ostvarivanja ljudskog dostojanstva za svaku ljudsku jedinku kroz nesmetani razvoj i realizaciju njezine

1 Ljudska prava su nedjeljiva, opća i međuovisna. Razlikuju se "različite dimenzije ili kategorije ljudskih prava: građanska i politička prava ... gospodarska, socijalna i kulturna prava", a u "osamdesetim godinama 20. stoljeća još je jedna kategorija ljudskih prava stekla priznanje: pravo na mir, pravo na razvoj i pravo na zdrav okoliš"; šire u Razumijevanje ljudskih prava - Priručnik o obrazovanju za ljudska prava, izdavač Europski centar za izobrazbu i istraživanje o ljudskim pravima i demokraciji, Graz, te Istraživačko-obrazovni centar za ljudska prava i demokratsko građanstvo Filozofskog fakulteta Sveučilišta u Zagrebu, 2003., str. 23.

2 Ljudska prava i temeljne slobode u pravilu se definiraju kao ona prava i slobode koje "pripadaju svim osobama, svakom ljudskom biću bez obzira na to je li građanin - državljanin neke države ili nije." Za razliku od njih, "prava i slobode nacionalnih manjina jesu ljudska prava i slobode pripadnika nacionalne manjine i manjine kao kolektiviteta koji se etničkim, vjerskim i jezičnim obilježjima, kao i običajima i kulturnom tradicijom razlikuje od većine stanovništva dotične države. Dijalektičkim jezikom govoreći, ljudska se prava i slobode prema pravima i slobodama nacionalnih manjina i njihovih pripadnika odnose kao cjelina prema dijelu, i obratno." Vidjeti: Arlović, M.; Pravo nacionalnih manjina u Republici Hrvatskoj, Novi informator, Zagreb, 2015., str. 93.

3 Vidjeti članak 1. Okvirne konvencije za zaštitu nacionalnih manjina (Narodne novine-Međunarodni ugovori, br. 14/1997.).

4 Europske vrijednosti koje čine temelje Europske unije jasno su pobrojane npr. u članku 2. Ugovora o Europskoj uniji i Ugovora o funkcioniranju Europske unije, dokument 2010/C 82/01, pročišćene inačice. 
osobnosti u sklopu vrednota demokratskog društva unutar društvene i državne zajednice. Tako postavljena želja za postizanjem legalnog i legitimnog cilja u pravnoj regulaciji, zaštiti i ostvarivanju ljudskih (uključivo i manjinskih) prava i temeljnih sloboda implicira postizanje jednakosti, ravnopravnosti kod njihova formalnog propisivanja u pravnim aktima, te napose u njihovoj stvarnoj realizaciji. Naime, današnji demokratski svijet i njegovo kulturološko civilizacijsko nasljeđe ne smije se i ne može pomiriti s činjenicom da su ljudska prava i temeljne slobode zaštićeni i ostvaruju se samo na formalnoj razini, već ona moraju biti zaštićena i realno ostvariva u društvenoj zbilji. Pored toga, uvijek treba imati u vidu da su ljudska prava i temeljne slobode (uključivo i manjinska), iako veoma značajna vrednota u demokratskim društvima, samo jedna od njih koje kao cjelina čine osnovu za ustroj društvene i državne zajednice. Mnoge države i njihove asocijacije stoga vrlo često u svoje ustave, odnosno temeljne akte unose bilo enumerativno bilo neke najvažnije vrednote kao primjer na kojima se one utemeljuju kao društvene i državne zajednice, neovisno radi li se o unitarnom ili njihovu složenom ustroju. I jedan i drugi pristup s ustavnopravnog, doktrinarnog pa i nomotehničkog aspekta ima i te kako svoje opravdanje. Tim više ako se te odredbe njihovih akata sagledavaju u kontekstu njihove cjelovitosti, a osobito u onom dijelu koji čini zajedničke odredbe u kojem su uz vrednote naznačeni ciljevi ${ }^{5}$ koji se žele postići takvim pravnim aktom, te napose ako se posebnom odredbom utvrđuju pravna načela za njihovo tumačenje, primjenu i provedbu u odnosu na konkretne slučajeve. Dakako, primjere takvog pravnog normiranja puno je lakše pronaći u odnosu na ustavne akte pojedinih država, međutim nisu nepoznati ni kad su u pitanju njihove asocijacije. Osim saveznih država, za takav primjer je, vjerojatno, najmjerodavnija Europska unija i njezini Ugovori o Europskoj uniji te o funkcioniranju Europske unije. ${ }^{6}$ Posebni značaj ovakvog pristupa pored inoga proizlazi i iz mogućnosti da se prilikom raspravljanja o pojedinoj vrednoti odvoje ona pravna načela koja su osobito karakteristična za nju, njezino tumačenje, primjenu i provedbu. To dakako, ovisno o konkretnom ustavnom pitanju u objektivnom ustavnom sporu (apstraktne kontrole ustavnosti i zakonitosti ili postupanja radi zaštite ljudskih prava i temeljnih sloboda), ne isključuje, u mjeri kojom traži taj spor, raspravljanje uz njih i ostalih društvenih vrednota te pravnih načela na kojima se one ostvaruju. Kad je u pitanju vrednota kao ljudska (i manjinska) prava i temeljne slobode, za njezina tumačenja, primjenu i provedbu napose su značajna načela: zabrane diskriminacije, ravnopravnosti i jednakosti, razmjernosti i pravičnosti itd. U ovom radu ja se neću baviti njima, osim u onom dijelu koje će mi biti nužno potrebno da obradim jedan dio, moglo bi se reći podnačelo načela zabrane diskriminacije koje zapravo egzistira kao posebno načelo, a odnosi se na tumačenje, provedbu i primjenu pravnog uređivanja, zaštite i ostvarivanja ljudskih prava i temeljnih sloboda pripadnika nacionalnih (i drugih) manjina i njihovih kolektiviteta. Radi se, kao što je poznato, o načelu pozitivne diskriminacije.

5 Ilustracije radi, može se kao primjer navesti članak 3. Ugovora o Europskoj uniji, op. cit.

6 Ugovori o Europskoj uniji stupili su na snagu 1. prosinca 2009. 


\section{MJERODAVNO PRAVO ZA PRISTUP POJMU (ZABRANE) DISKRIMINACIJE}

Načelo pozitivne diskriminacije u pravilu nije po svom sadržaju, vrstama i opsegu ekspresis verbis regulirano u pravnim aktima, napose kad se radi o onima koje nazivamo univerzalnima. Lakše ga je prepoznati posrednim putem primjenom metode zaključivanja argumentom a contrario i teleološke metode $\mathrm{u}$ analizi pravnih odredaba odgovarajućih pravnih akata kojima njihov donositelj državnim i drugim tijelima javne vlasti nalaže određena ponašanja i djelovanja. ${ }^{7}$ Zapravo rasprava o načelu pozitivne diskriminacije kao prethodno pitanje zahtijeva njegovo pojmovno određenje, $s$ jedne strane, a s druge strane i njegovo razgraničenje, od pojma diskriminacije, odnosno zabrane diskriminacije. Kako se u ovom radu bavimo načelom pozitivne diskriminacije s pravnog aspekta prema pravima i slobodama nacionalnih manjina kao posebnom obliku očitovanja ljudskih prava i temeljnih sloboda, to ćemo se, prije nego ga definiramo, osvrnuti na pravnu regulaciju ovih pojmova u pravnim aktima univerzalnog i regionalnog (prava EU-a) te nacionalnog prava Republike Hrvatske. Ovo i zbog toga što ti akti čine bilo izravne (direktne), bilo neizravne (indirektne) izvore pravnog okvira za pravnu analizu i određenje te njihovo razgraničenje pojmova ovih načela. Univerzalni nadnacionalni pravni akti, kako sam već rekao, ne sadrže izrijekom utvrđenu odredbu koja propisuje što se smatra u pojmovnom smislu pod pozitivnom diskriminacijom i na koje odnose i pitanja se ona odnosi. No, oni sadrže odredbe koje propisuju što se razumijeva pod diskriminacijom, zabranom diskriminacije te neki od njih odredbe o mjerama koje bi se same po sebi mogle smatrati diskriminatornima, ali se za sebe u odnosu na društvene odnose koje reguliraju i na koje se odnose takvima ne smatraju niti se smiju takvima tumačiti i smatrati. Zapravo pod tim mjerama (pozitivnim) krije se načelo pozitivne diskriminacije prema nacionalnim (i drugim) manjinama. Najznačajniji ${ }^{8}$ nadnacionalni (univerzalni) pravni (ili pravnopolitički) propisi koji u sebi sadrže odredbe koje se odnose na ova pitanja jesu: Povelja ujedinjenih naroda, ${ }^{9}$

\footnotetext{
Dakako, neovisno o tome radi li se o tzv. pozitivnim ili negativnim obvezama države. Više o pozitivnom i negativnom poimanju državnih obveza vidjeti npr. kod Vesne Batistić Kos: Pozitivne obveze prema Europskoj konvenciji za zaštitu ljudskih prava i temeljnih sloboda, Zagreb, 2012., str. 22-25.

8 U ovom sam radu kao najznačajnije nadnacionalne (univerzalne) akte uzeo one navedene u tekstu, no to ni izbliza ne znači da je time njihova lista konačna i iscrpljena. Naime, uz njih bi se mogli navesti u ove izvore i sljedeći: Konvencija o ukidanju svih oblika diskriminacije žena (Narodne novine - Međunarodni ugovori broj 12/93.), Konvencija o zaštiti ljudskih prava i dostojanstva ljudskog bića u pogledu primjene biologije i medicine: Konvencija o ljudskim pravima i biomedicini (Narodne novine - Međunarodni ugovori broj 13/03.), Konvencija Međunarodne organizacije rada (br. 100) o jednakosti plaća radnika i radnica za rad jednake vrijednosti (Narodne novine - Međunarodni ugovori broj 3/00.), Konvencija Međunarodne organizacije rada (br. 111) o zabrani diskriminacije u zvanju i zapošljavanju (Narodne novine - Međunarodni ugovori broj 5/99.), Konvencija o pravima osoba s invaliditetom (Narodne novine - Međunarodni ugovori broj 6/07. i 5/08.), Bečka konvencija o pravu međunarodnih ugovora između država i međunarodnih organizacija ili između međunarodnih organizacija (Narodne novine - Međunarodni ugovori broj 1/94.) itd. itd.

9 Povelja Ujedinjenih naroda objavljena je u Narodnim novinama - Međunarodni ugovori broj 15/93.
} 
Opća deklaracija o pravima čovjeka, ${ }^{10}$ Međunarodni pakt o građanskim i političkim pravima, ${ }^{11}$ Međunarodni pakt o ekonomskim, socijalnim i kulturnim pravima, ${ }^{12}$ Konvencija o ukidanju svih oblika rasne diskriminacije ${ }^{13}$ itd.

\subsection{O univerzalnom nadnacionalnom mjerodavnom pravu}

Završetkom Drugog svjetskog rata i donošenjem Povelje Ujedinjenih naroda, započinje novo doba u razvoju i zaštiti ljudskih prava i temeljnih sloboda, a slijedom toga i evolutivni kvalitetni razvoj načela diskriminacije, odnosno njezine zabrane.

Povelja već u članku 1. stavku 1. točki 3. sadrži načelo zabrane diskriminacije, propisujući da se međunarodna suradnja ostvaruje razvijanjem i poticanjem "poštovanja prava čovjeka i osnovnih sloboda za sve bez razlike rase, spola, jezika ili vjere". U sadržajnom smislu, citirano stajalište gotovo se ponavlja u članku 13. stavku 1. točki b. Povelje. Povelja nadalje u članku 55. točki c. propisuje da će Ujedinjeni narodi stvarati uvjete ustaljenosti i blagostanja, potrebne za mirne i prijateljske odnose među narodima, unapređivati i "opće i stvarno poštovanje prava čovjeka i osnovnih sloboda za sve bez razlike rase, spola, jezika ili vjere."

Poslije "Biblije", najčitanija i najprevođenija na druge jezike jest knjiga "Opća deklaracija o pravima čovjeka" u cijelom svijetu. Već ta činjenica ukazuje na to koliku pozornost je ovaj univerzalni nadnacionalni akt izazvao u cjelokupnoj svjetskoj javnosti, neovisno o tome što on po svojoj pravnoj prirodi nije općeobvezatni pravni akt. Unatoč tome, bilo bi sasvim pogrešno tumačiti ga kao potpuno neobvezujući akt. Zašto? Zato što njegova obvezatnost proizlazi iz dobrovoljno iskazane volje država koje su je prihvatile ili potpisale da pretoče, razrade, pravno urede i zaštite vrednote sadržane u njoj, na njezinim načelima, radi ostvarivanja ciljeva i ideala za koje se ona zalaže i zbog kojih je donesena. Na njezinu obligatnost utječe, sasvim sigurno, sam autoritet tijela koje ju je donijelo, ali bez sumnje i sam supstancijalni sadržaj koji se odnosi na vrednote, ideale, slobode i ciljeve kojima stremi svako ljudsko biće, te je stoga kao izraz civilizacijskog naslijeđa općeprihvatljiva za sve, neovisno o tome ima li ili nema snagu pravnog propisa. Ona je stoga zapravo izraz napisanih moralnih vrednota koje želi imati i ostvariti svaka društvena i državna zajednica. U političkopravnom pogledu nju bi se moglo definirati kao prethodni (preparatornopravni) akt koji sadrži vrednote, načela, ideale i ciljeve, koje sve članice koje su je potpisale ili prihvatile žele pravno ozakoniti u svojim ustavnopravnim sustavima. Utjecaj ovog dokumenta na pravno uređivanje suvremenog demokratskog svijeta, njegovih vrednota i sloboda gotovo je nezamjenjiv i nemjerljiv. U tom kontekstu treba sagledati i njezine odredbe koje se odnose na uređivanje i zaštitu ljudskih

10 Opću deklaraciju o pravima čovjeka usvojila je Opća skupština UN-a i proglasila ju je 10. prosinca 1948. g., vidjeti njezin tekst kod Hrženjak, J.; Međunarodni i europski dokumenti o ljudskim pravima, Informator, Zagreb, 1992. g., str. 123-126.

11 Narodne novine - Međunarodni ugovori broj 12/93., 7/95. i 11/95.

12 Narodne novine - Međunarodni ugovori broj 12/93.

13 Narodne novine - Međunarodni ugovori broj 12/93. 
(uključivo i manjinskih) prava i temeljnih sloboda te važnih načela na kojima počiva njihovo uređenje, zaštita i ostvarivanje kao što je npr. načelo zabrane diskriminacije. Opća deklaracija već u članku 1. jezgrovito utvrđuje i proširuje temelje za zabranu diskriminacije, polazeći od osnovnih karakteristika koje određuju ljudska prava i temeljne slobode. Stoga ona u njemu propisuje "sva se ljudska bića rađaju slobodna i jednaka u dostojanstvu i pravima". No, odlučujući je članak 2. Deklaracije, jer on pristupa zabrani diskriminacije ne samo za svako ljudsko biće u pogledu njegovih ljudskih (uključivo i manjinskih) prava i temeljnih sloboda, već i u odnosu na njegovu pripadnost zemlji i teritoriju.

Zbog toga članak 2. zavređuje da ga se u cijelosti navede. On glasi:

"Svakom pripadaju sva prava i slobode proglašene u ovoj Deklaraciji bez ikakvih razlika u pogledu rase, boje, spola, jezika, vjere, političkog ili drugog mišljenja, nacionalnog ili društvenog porijekla, imovine, rođenja ili drugih okolnosti.

Dalje, neće se praviti nikakva razlika na osnovi političkog, pravnog ili međunarodnog statusa zemlje ili teritorija kojoj neka osoba pripada, bilo da je ona nerazvijena, pod starateljstvom, nesamoupravna, ili da joj je suverenost na koji drugi način ograničena."

$\mathrm{Na}$ članak 2. supstancijalno se nadovezuje članak 7., kojim Deklaracija primjenom nomotehničkog načela tzv. generalne klauzule pristupa problemu diskriminacije odnosno njezinoj zabrani. Takvom metodom izbjegnuta je metoda enumeracije odnosno nabrajanja različitih osnova diskriminacije ili njezine zabrane $\mathrm{s}$ jedne strane, a s druge strane ona je ostala otvorena pod pojam diskriminacije i njezine zabrane podvesti bilo koju novu osnovu koja bi mogla nastati razvojem društvenih odnosa. Takvo opredjeljenje, po mom mišljenju, Deklaracija je provela u članku 7. koji glasi:

"Svi su pred zakonom jednaki i imaju pravo bez ikakve razlike na podjednaku zaštitu zakona. Svi imaju pravo na jednaku zaštitu protiv bilo kakve diskriminacije kojom se krši ova Deklaracija, i protiv svakog poticaja na ovakvu diskriminaciju."

Sukladno ovom članku, Deklaracija sadržajno uređuje problem diskriminacije i njezine zabrane u nekim društvenim odnosima koji su predmet njezina reguliranja, a gdje se to pitanje među ljudima može pojaviti.

Polazeći od Povelje Ujedinjenih naroda i Opće deklaracije, OUN je problemu diskriminacije i njezine zabrane cjelovitije pristupio 1966. g. donijevši dva ugovora i to: Međunarodni pakt o građanskim i političkim pravima te Međunarodni pakt o ekonomskim, socijalnim i kulturnim pravima. Međunarodni pakt o građanskim i političkim pravima problemu diskriminacije i njezinoj zabrani pristupa u članku 2. stavak 1., te u člancima 3., 14., 24., 25. i 26. Za našu temu posebno su značajni članak 2. stavak 1. i članak 26., ne samo zbog toga što oni dosljedno prate i razrađuju ova pitanja kako im je pristupila Deklaracija, već i zbog toga što osnove moguće diskriminacije proširuje i njezine zabrane utvrđuje i na osnovi nacionalnosti, a osobito zbog toga što u članku 26. nesporno slijedi obvezu zabrane svake 
diskriminacije, a na temelju nekih osnova temeljem kojih dolazi do diskriminacije na neka od pojedinih prava i sloboda. Naime, ovim člankom od država članica traži se da svojim zakonima propišu kao pravilo zabranu svake diskriminacije, dok se kao primjer navode one osnove koje Deklaracija propisuje u članku 2. stavku 1. te sam Pakt u svom članku 2. stavku 1. Da je tome tako razvidno je iz samog sadržaja članka 26. Međunarodnog pakta o građanskim i političkim pravima koji glasi:

"Sve osobe jednake su pred zakonom i imaju pravo bez ikakve diskriminacije na jednaku zaštitu zakona. U tome treba da zakon zabrani svaku diskriminaciju i da zajamči svim osobama jednaku i djelotvornu zaštitu protiv diskriminacije na temelju bilo kojeg razloga kao što su rasa, boja kože, spol, jezik, vjera, političko ili drugo mišljenje, nacionalno ili socijalno podrijetlo, imovina, rad ili koja god druga okolnost" (sve podcrtao autor).

Drugi članci tog pakta uređuju zabranu diskriminacije po nekoj od konkretnih osnova u društvenim odnosima, pa o njima neću posebice govoriti. Sličan pristup ovoj problematici ima i Međunarodni pakt o ekonomskim, socijalnim i kulturnim pravima, što proizlazi npr. iz njegova članka 2. stavka 2. No, treba ponoviti specifičnu razliku koja postoji među njima, a na koju ukazuje Vesna Barić Punda. Naime, ona s pravom navodi: "Između dva pakta postoji razlika u mjerama (metodama) implementacije. Obvezu bezuvjetne implementacije države preuzimanju ratificiranjem Međunarodnog pakta o građanskim i političkim pravima, a nova formula postupovnog postizanja punog ostvarenja prava prihvaćena je $u$ Međunarodnom paktu o ekonomskim, socijalnim i kulturnim pravima." ${ }^{14}$

Navedeni akti OUN-a za borbu protiv diskriminacije imali su i imaju ogroman značaj, kako u državama članicama da svojim zakonima zabrane diskriminaciju tako i na nivou međunarodne zajednice. Oni su, naime, bili osnova i poticaj velikom broju specijaliziranih ustanova da pod okriljem OUN-a donesu pojedinačne deklaracije i konvencije kojima propisuju zabranu diskriminacije i osiguraju svim osobama jednaku i djelotvornu zaštitu protiv diskriminacije po bilo kojoj osnovi. Sve one su važne i iznimno značajne za provođenje zaštite svih i svakoga od diskriminacije po bilo kojoj osnovi. No, uz naprijed navedene nadnacionalne univerzalne pravne akte, možda je potrebno još posebno istaći i Konvenciju o ukidanju svih oblika rasne diskriminacije. ${ }^{15}$ Naime, ona najprije, u članku 1. jasno govori što pod pojmom diskriminacije podrazumijeva, pa njime propisuje:

"U ovoj konvenciji izraz 'rasna diskriminacija' odnosi se na svako razlikovanje, isključivanje, ograničavanje ili davanje prvenstva koji se zasnivaju na rasi, boji, precima, nacionalnom ili etničkom porijeklu koji imaju za svrhu ili za rezultat da unište ili da ugroze priznavanje, uživanje ili vršenje, pod jednakim uvjetima, prava čovjeka i osnovnih sloboda na političkom, ekonomskom, socijalnom i kulturnom polju ili na svakom drugom polju javnog života".

14 Vidjeti pobliže članak 2. stavak 2. Međunarodnog pakta o ekonomskim, socijalnim i kulturnim pravima (Narodne novine - Međunarodni ugovori broj 12/93.).

15 Konvencija o ukidanju svih oblika rasne diskriminacije objavljena je u Narodnim novinama Međunarodni ugovori broj 12/93. 
Drugo, pojmovno određenje diskriminacije odnosno njezine zabrane iz ovog članka Konvencije je uglavnom (ponekad s manjim odstupanjima) prihvaćeno kako u doktrinarnom određenju ovog pojma tako i u jurisprudenciji kao osnova za tumačenje sadržaja i opsega nediskriminacije.

Treće, ona je imala kao definicija polaznu osnovu u tumačenju i razradi nadnacionalnog univerzalnog uređenja diskriminacije i zabranu diskriminacije $u$ nadnacionalnim regionalnim (npr. Europi) i u nacionalnim pravnim aktima.

Četvrto, Konvencija se svojim širokim obuhvatom u definiciji ovog pojma ne zadržava samo na njegovu definiranju u odnosu na rasnu diskriminaciju već ga proširuje primjerice na pretke, nacionalno ili etničko podrijetlo. Tako je prvi put otvoren prostor za zabranu diskriminacije po bilo kojoj osnovi za pripadnike nacionalnih ili etničkih manjina, što je ne samo proširenje za njih osnova zabrane diskriminacije iz članka 27. Međunarodnog pakta o građanskim i političkim slobodama, nego i izjednačavanje zabrane diskriminacije prema njima kao i za svako ljudsko biće u odnosu na ljudska prava i temeljne slobode. Time je prešutno ovom odredbom navedene Konvencije prihvaćen i pravno utvrđen status prava i sloboda pripadnika nacionalnih manjina kao što ih imaju ljudska prava i temeljne slobode, odnosno njihov su sadržajni dio.

\subsection{O regionalnom nadnacionalnom europskom mjerodavnom pravu}

Zabrana diskriminacije smatra se jednim od temeljnih načela za priznanje, ostvarivanje i zaštitu ljudskih prava i temeljnih sloboda, uključivo i nacionalnih i drugih manjina i u nadnacionalnim regionalnim dokumentima. Na području Europe jedna od svakako najznačajnijih jest Konvencija za zaštitu ljudskih prava i temeljnih sloboda koju su donijele države članice Vijeća Europe. ${ }^{16}$ Ta je Konvencija odgovor Vijeća Europe na prihvaćanje i daljnju zaštitu ljudskih prava i temeljnih sloboda propisanih Općom deklaracijom o zaštiti ljudskih prava. Kao takva, ona je europski standard zaštite ljudskih prava i temeljnih sloboda. Specifična je po dvije osnove koje je obilježavaju. Prvo, ona se neposredno primjenjuje. Drugo, kad je u pitanju zabrana diskriminacije, upravo zbog svoje neposredne primjene, iz nje proizlazi druga njezina osobina, a to je da se njome zabranjuje diskriminacija samo onih prava i sloboda koja su njome propisana. ${ }^{17}$ Nositelji neposredne primjene i provedbe zaštite ljudskih prava i temeljnih sloboda jesu države članice koje su je prihvatile. No, ako države članice nisu u stanju osigurati zaštitu ljudskih prava i sloboda svakom ljudskom biću pod svojom jurisdikcijom u propisanom postupku pred nadležnim tijelima, Konvencija je propisala mogućnost supsidijarne zaštite takvim osobama pred nadležnim Europskim sudom za zaštitu ljudskih prava u Strasbourgu. Pružajući zaštitu podnositeljima zahtjeva, Europski je sud za ljudska prava kroz dugogodišnju

16 Europska konvencija za zaštitu ljudskih prava i temeljnih sloboda objavljena je u Konvenciji o ukidanju svih oblika rasne diskriminacije, u Narodnim novinama - Međunarodni ugovori broj 6/99. pročišćeni tekst, 8/99., 14/02., i 9/05.

17 Vidjeti pobliže članak 14. Konvencije za zaštitu ljudskih prava i temeljnih sloboda. 
praksu izgradio stajališta da se njihova zaštita mora osigurati ne samo na formalnoj već i na realnoj razini. Isto tako, ovaj je Sud prihvatio definiciju i samo tumačenje diskriminacije te zabrane diskriminacije kako ih određuje Konvencija o ukidanju svih oblika rasne diskriminacije kao osnovu za izgradnju svojih stajališta u pogledu zabrane diskriminacije, što je, uz proširivanje sadržaja ljudskih prava i temeljnih sloboda koja se smatraju konvencijskima, ubrzo izazvalo potrebu proširenja zabrane diskriminacije na njezinu opću zabranu. To je učinjeno člankom 1. njezina Protokola broj 12. kojim je propisano: "uživanje svakog prava zakonom propisanog mora se osigurati bez diskriminacije po bilo kojoj osnovi, kao što su spol, rasa, boja kože, jezik, vjera, političko i drugo mišljenje, nacionalno ili socijalno podrijetlo, pripadnost nacionalnoj manjini, bogatstvo, rođenje ili koja god druga okolnost."

Zabranu diskriminacije kao opću zabranu na osnovi generalne klauzule izrečene riječima: "zabranjena je bilo kakva diskriminacije na osnovi pripadnosti nacionalnoj manjini"18 propisuje i Okvirna konvencija za zaštitu nacionalnih manjina koju je donijelo Vijeće Europe. ${ }^{19} \mathrm{O}$ njoj će biti više riječi infra kad budemo govorili o uvjetima i kriterijima koji se moraju steći da bismo mogli primjenjivati načelo pozitivne diskriminacije.

Što se pak tiče pristupa diskriminaciji i njezinoj zabrani, smatram da je svojom regulacijom tog pitanja najviše standarde postigla Europska unija sa svojim tijelima, i to kako na načelnoj tako i na konkretnoj razini. To, dakako, ne znači da i druge asocijacije i njihova tijela nisu pristupala ovim pitanjima i nastojala ih urediti. Baš naprotiv. No za razliku od njih, Europska unija ta je pitanja uredila pravnoobvezujućim aktima najviše razine koja se s pravom tumače kao njezini ustavnopravni akti, a to su Ugovor o Europskoj uniji i Ugovor o funkcioniranju Europske unije. Dakako, ovdje treba imati u vidu specifično stajalište Europske unije u pogledu na pravno uređenje ljudskih prava i temeljnih sloboda izraženo expresis verbis u članku 6. Ugovora o Europskoj uniji. ${ }^{20}$ Tim člankom Europska unija priznala je sva prava, slobode i načela određena Poveljom EU-a o temeljnim pravima s jedne strane, a s druge njoj kao pravnom aktu dodijelila istu pravnu snagu koju imaju Ugovori, tj. imaju status njezinih osnivačkih akata.

U stavku 2. tog članka Unija je propisala da pristupa Europskoj konvenciji za zaštitu ljudskih prava i temeljnih sloboda. Istim člankom u stavku 3. propisala je temeljna prava "kako su zajamčena Europskom konvencijom za zaštitu ljudskih prava i temeljnih sloboda $\underline{i \text { kako proizlaze iz ustavnih tradicija zajedničkih državama }}$ članicama, čine opća načela prava Unije" (sve podcrtao autor).

Pored toga, Unija je člankom 6. stavkom 1. podstavkom 2. propisala da se "odredbama Povelje, ni na koji način, ne proširuju nadležnosti Unije kako su

18 Vidjeti članak 4. stavak 1. Okvirne konvencije za zaštitu nacionalnih manjina, Narodne novine Međunarodni ugovori broj 14/97.

19 Okvirna konvencija za zaštitu nacionalnih manjina objavljena je u Narodnim novinama Međunarodni ugovori broj 14/97.

20 Ugovor o Europskoj uniji objavljen je zajedno s Ugovorom o funkcioniranju Europske unije u dokumentu br. 2010/C 83/01 pročišćene inačice. 
utvrđeni u Ugovorima, a u podstavku 3. "Prava, slobode i načela Povelje tumače se u skladu s općim odredbama glave VII. Povelje kojima se uređuje njezino tumačenje i primjena uzimajući u obzir objašnjenja iz Povelje kojima se određuju izvori tih odredaba." Temeljem članka 6. Ugovora mogli bismo zaključiti da su njime u cjelini njihova sadržajnog korpusa uključena sva prava i temeljne slobode koje priznaju Povelja EU-a o temeljnim pravima te Konvencija za zaštitu ljudskih prava i temeljnih sloboda, pa i ona koja se odnose na pitanje diskriminacije odnosno njezine zabrane. Upravo stoga osnivački Ugovori EU-a danas su najcjelovitiji pravni akt nadnacionalnog prava kojim se uređuje zabrana diskriminacije, pogotovo ako se Konvencija za zaštitu ljudskih prava i temeljnih sloboda sagledava u njezinu proširenom sadržaju s pripadajućim protokolima. Prethodno smo se osvrnuli na članak 14. Konvencije i Protokol broj 12, odnosno njegov članak 1. kojim se propisuje zabrana diskriminacije kao generalno pravilo. Na sličan način to pitanje uređuje i Povelja koja u članku 21. propisuje:

"Zabranjuje se bilo kakva diskriminacija na temelju spola, rase, boje kože, etničkog ili socijalnog podrijetla, genetskih osobina, jezika, vjere ili uvjerenja, političkoga ili bilo kakvoga drugog mišljenja, pripadnosti nacionalnoj manjini, imovine, rođenja, invalidnosti, dobi ili spolnog usmjerenja.

2. Unutar područja primjene Ugovora i ne dovodeći u pitanje bilo koju njihovu posebnu odredbu, zabranjena je svaka diskriminacija na temelju državljanstva."

\subsection{Hrvatsko (nacionalno) mjerodavno pravo}

Navedene odredbe ovih (i drugih) najbitnijih nadnacionalnih akata valjalo je na odgovarajući način preuzeti, precizirati i razraditi u pravnim aktima nacionalnog prava, da bi države članice preuzete obveze mogle ispuniti na svom suverenom teritoriju. Pravni propisi kojima je uređena zabrana diskriminacije čine izvore ovog prava na nacionalnoj razini.

Prilikom određivanja obuhvata zabrane diskriminacije, ili još šire tzv. antidiskriminacijskog prava, ${ }^{21}$ prije svega valja poći od pravnog monizma koji obilježava ustavnopravni poredak Republike Hrvatske. Pravni monizam u Republici Hrvatskoj hrvatski ustavotvorac utvrdio je člankom 141. Ustava, propisujući:

"Međunarodni ugovori koji su sklopljeni i potvrđeni u skladu s Ustavom i objavljeni, a koji su na snazi, čine dio unutarnjega pravnog poretka Republike Hrvatske, a po pravnoj su snazi iznad zakona. Njihove se odredbe mogu mijenjati ili ukidati samo uz uvjete i na način koji su u njima utvrđeni, ili suglasno općim pravilima međunarodnog prava."22

21 Pojam "antidiskriminacijsko pravo" koristi Tena Šimonović Einwalter u svom radu "Antidiskriminacijsko pravo i Zakon o suzbijanju diskriminacije", u Zborniku radova Vodič uz zakon o suzbijanju diskriminacije, Zagreb, 2009., str. 11.

22 Ustav Republike Hrvatske, Narodne novine broj 85/10. - pročišćeni tekst. 
Slijedom takvog monističkog pristupa, ukupnost izvora antidiskriminacijskog prava čiju osnovu čini načelo zabrane diskriminacije u Republici Hrvatskoj čine odgovarajuće odredbe Ustava Republike Hrvatske, ustavnih zakona, zakona i drugih propisa te pravnih akata nadnacionalnog univerzalnog prava, nadnacionalnog regionalnog prava (Vijeća Europe i Europske unije) ako ispunjavaju kriterije i udovoljavaju uvjetima koje propisuje citirani članak 141. Ustava. Kako smo se na neke od najvažnijih pravnih akata nadnacionalnog prava u prethodnom tekstu već osvrnuli, u nacionalnim izvorima kratko ću se baviti samo nekima od najznačajnijih odredbi koje se odnose na zabranu diskriminacije, a u svojoj suštini čine uži dio cjeline monističkog modela hrvatskog ustavnopravnog poretka. Točnije samo onima koje je kao pravne akte donio hrvatski ustavotvorac - zakonodavac.

Ustav Republike Hrvatske, uz načelo jednakosti i ravnopravnosti, pred zakonom je propisao načelo zabrane diskriminacije kao jedno od temeljnih načela za propisivanje, ostvarivanje i zaštitu ljudskih prava i temeljnih sloboda, uključivo i prava i slobode nacionalnih (i drugih) manjina. Zbog potreba ovoga rada, više će biti samo riječi infra o zabrani diskriminacije.

Sama zabrana diskriminacije u ustavnopravnom poretku Republike Hrvatske prihvaćena je kao ustavna kategorija.

Već odgovarajućim teleološkim tumačenjem članka 3. Ustava kojim se utvrđuju najviše vrednote ustavnog poretka, jednakost, nacionalne ravnopravnosti i ravnopravnosti spolova lako je iščitati zabranu diskriminacije kao jedno od načela ustavnog poretka Hrvatske. No, Ustav Republike Hrvatske pored toga ovo načelo izrijekom propisuje kao ustavnu kategoriju u svom članku 14. riječima: "Svatko u Republici Hrvatskoj ima prava i slobode, neovisno o njegovoj rasi, boji kože, spolu, jeziku, vjeri, političkom ili drugom uvjerenju, nacionalnom ili socijalnom podrijetlu, imovini, rođenju, naobrazbi, društvenom položaju ili drugim osobinama. Svi su pred zakonom jednaki." Kako je iz citiranog članka vidljivo, Ustav je a) utvrdio zabranu diskriminacije kao ustavnu kategoriju, b) on je u stavku 1. ovog članka riječima "ili drugim osobinama" ostavio otvorenu listu za neke, moguće nove, diskriminacijske osnove. Dakle on nije izvorno generalnom odredbom unaprijed zabranio svaku diskriminaciju, iako je ona u Hrvatskoj baš tako zabranjena temeljem odgovarajućih odredbi nacionalnih pravnih akata koji po Ustavu RH čine dio ustavnopravnog poretka.

Do donošenja Zakona o suzbijanju diskriminacije antidiskriminacijsko zakonodavstvo u Republici Hrvatskoj obuhvaćalo je pojedine odredbe sadržane u člancima različitih zakona kojima se zabranjivala diskriminacija. Neki su od njih npr. Ustavni zakon o pravima nacionalnih manjina, Zakon o radu, Zakon o ravnopravnosti spolova, Zakon o državnim službenicima, Kazneni zakon itd. Za potrebe ovoga rada i obradu njegove teme nastavno ću se više uz već izloženo osloniti, pored odredbi Ustava Republike Hrvatske, na neke od odredbi sadržane u člancima Zakona o suzbijanju diskriminacije i Ustavnom zakonu o pravu nacionalnih manjina, obrađujući pojedina pitanja u svezi sa zabranom odnosno pozitivnom diskriminacijom. 


\section{POJMOVNO ODREĐENJE (ZABRANE I POZITIVNE) DISKRIMINACIJE}

S pravom se može reći da je pojmovno određenje diskriminacije kakvo danas imamo na doktrinarnoj razini, u ustavnosudskoj praksi, pa i u praksi ESLJP-a, utemeljeno na odredbama međunarodnih pravnih akata univerzalnog i regionalnog nadnacionalnog karaktera. Među njima osobito su značajan (po mom mišljenju dominantan) utjecaj imali Konvencija o ukidanju svih oblika rasne diskriminacije te stajalište Međunarodnog suda koji je tu definiciju prihvatio kao vjerodostojno tumačenje značaja i dosega odredbe o nediskriminaciji Povelje UN-a. ${ }^{23}$ Navedeno stajalište potvrđuje ustavnosudska praksa Ustavnoga suda Republike Hrvatske, ali i praksa ESLJP-a. ${ }^{24}$ Stoga je sasvim očekivano da je njihov utjecaj prisutan i u pravnoj doktrini prilikom određivanja pojma diskriminacije, te u konačnici i u zakonodavnoj praksi nadležnih zakonodavnih tijela.

Određujući se prema pojmu diskriminacije, ESLJP je u jednom predmetu zauzeo stajalište da "diskriminacija predstavlja različito postupanje, bez objektivnog i nacionalnog opravdanja, prema osobama u relativno sličnim situacijama." ${ }^{25} \mathrm{U}$ drugom predmetu on shvaća diskriminaciju polazeći od članka 14. Konvencije kao "različito postupanje" prema osobama u istovrsnim ili bitno sličnim okolnostima ako "ne postoji razumno i objektivno opravdanje", odnosno ako ne postoji "razuman odnos proporcionalnosti između upotrijebljenih sredstava te cilja koji se želi ostvariti."26

Ustavni sud Republike Hrvatske, uz to što prihvaća stajalište ESLJP-a kod određivanja pojma diskriminacije, i sam se odredio glede njega u pojedinim svojim odlukama.

Pri svom pristupu određivanju pojma diskriminacije Ustavni sud Hrvatske polazi od članka 14. Ustava koji po njegovu mišljenju zakonodavcu ne zabranjuje da prava i obveze "pojedinih istovrsnih ili sličnih skupina uređuje različito, ako se time ispravljaju postojeće nejednakosti među tim skupinama ili za to postoje drugi opravdani, na Ustavu utemeljeni razlozi.

Različito uređenje prava i obveza, međutim, smatrat će se diskriminirajućim ako propisano razlikovanje nema objektivnog i razumnog opravdanja, odnosno ako se time ne ostvaruje legitimni cilj ili ako ne postoji razmjernost između propisane zakonske mjere i cilja koji se nastoji postići."27

23 Tako smatra i Buergenthal, T.; vidjeti njegovu knjigu Međunarodna ljudska prava, Zagreb, 1997. str. 57.

24 Vidjeti Odluku Ustavnog suda Republike Hrvatske broj: U-III-3138/2002, od 7. veljače 2007. ili presudu ESLJP-a u predmetu Willis protiv Ujedinjenog Kraljevstva, zahtjev broj: 36042/97.

25 Predmet ESLJP-a Willis protiv Ujedinjenog Kraljevstva, zahtjev broj: 36042/97 §48, 2002-IV.

26 ESLJP, vidjeti predmet Abdulaziz, Cabales i Balkandali protiv Ujedinjenog Kraljevstva, zahtjev broj: 9214/80; 9473/81, §72.

27 Odluka Ustavnog suda broj: U-I-764/2004 od 21. ožujka 2007. (Narodne novine broj 34/07.), točka 12. 
Dr. sc. Mato Arlović: Pozitivna diskriminacija u regulaciji i zaštiti prava i sloboda pripadnika... Zbornik radova Pravnog fakulteta u Splitu, god. 56, 4/2019, str. 785-815

Hrvatski zakonodavac određuje diskriminaciju u članku 1. stavku 2. i 3. Zakona o suzbijanju diskriminacije pa propisuje:

(2) Diskriminacijom u smislu ovoga Zakona smatra se stavljanje u nepovoljniji položaj bilo koje osobe po osnovi iz stavka 1. ovoga članka, kao i osobe povezane s njom rodbinskim ili drugim vezama.

(3) Diskriminacijom se smatra i stavljanje neke osobe u nepovoljniji položaj na temelju pogrešne predodžbe o postojanju osnove za diskriminaciju iz stavka 1. ovoga članka." 28

$\mathrm{Na}$ temelju izloženih određenja pojma diskriminacije te navedenih pristupa ovoj problematici u aktima nadnacionalnog i nacionalnog pravnog uređivanja, mišljenja sam da se za sve oblike diskriminacije mogu poopćiti tri njezina obilježja (karakteristike). Prvo, uzroci diskriminacije osobne su karakteristike nositelja ljudskih prava i temeljnih sloboda kao što su primjerice: boja kože, rasa, spol, dob, nacionalno podrijetlo, uvjerenje ili opredjeljenje itd. Drugo, postojanje diskriminacije vezano je uz egzistenciju postupaka koji se smatraju diskriminacijskima, kao što su npr. razlikovanja, favoriziranje, isključenja, ograničenja i sl. Treće, postojanje ili nepostojanje diskriminacije povezano je sa svrhom, odnosno posljedicom diskriminacije. Diskriminacije jest sprečavanje "žrtava da ostvare svoja ljudska prava i temeljne slobode". Sukladno tome treba razlikovati različite oblike diskriminacije kao što su npr. izravna ili neizravna itd. ${ }^{29}$

Slijedom navedenih karakteristika, prethodno izloženim definicijama pojma diskriminacije moglo bi se, možda, prigovoriti glede njihove sveobuhvatnosti. Izbjegavajući moguće prigovore, opredjeljujem se za drugu definiciju koju smatram obuhvatnijom, a time i cjelovitijom, a ona glasi: "diskriminacija je svako razlikovanje, isključivanje, ograničavanje ili favoriziranje kojemu je cilj pojedincu i/ili skupini zanijekati jednakost u zaštiti, u pravima i slobodama. Posebno je opasna tzv. institucionalizirana diskriminacija, koja proizlazi iz zakona, vladajuće politike i običaja koji sustavno vode nejednakosti i diskriminaciji u društvu, organizaciji ili instituciji. Zapravo, posljedica svake diskriminacije po pravilu jest ugrožavanje ljudskog dostojanstva, jednakih prava i sloboda, svih koji su diskriminirani." ${ }^{30} \mathrm{Uz}$ izložene definicije mogli smo istaći i druge ${ }^{31}$ no ovime smo postigli svrhu potrebnu ovom radu. Do njih smo došli analizom pravnopolitičkih akata i doktrinarnih stajališta, relativno lako, jer svi prema diskriminaciji izravno komuniciraju.

28 Stavak 1. članka 1. Zakona o suzbijanju diskriminacije, Narodne novine broj 85/08. i 112/12. glasi:

"(1) Ovim se Zakonom osigurava zaštita i promicanje jednakosti kao najviše vrednote ustavnog poretka Republike Hrvatske, stvaraju se pretpostavke za ostvarivanje jednakih mogućnosti i uređuje zaštita od diskriminacije na osnovi rase ili etničke pripadnosti ili boje kože, spola, jezika, vjere, političkog ili drugog uvjerenja, nacionalnog ili socijalnog podrijetla, imovnog stanja, članstva u sindikatu, obrazovanja, društvenog položaja, bračnog ili obiteljskog statusa, dobi, zdravstvenog stanja, invaliditeta, genetskog naslijeđa, rodnog identiteta, izražavanja ili spolne orijentacije."

29 Preuzeto iz Razumijevanje ljudskih prava, Priručnik o obrazovanju za ljudska prava, str. 93. o. c.

30 Arlović, M., o. c. str. 411.

31 Tako npr. Pravni leksikon određuje diskriminaciju kao u "sociologiji, nejednako postupanje prema društvenim skupinama ili pojedincima; u gospodarstvu, mjera, postupak ili odluka kojima se netko stavlja u gospodarski nepovoljniji položaj od drugih", izd. Zagreb, 2007., str. 225. itd. 
Ostaje pitanje kako definirati pojam pozitivne diskriminacije kad u pravnopolitičkim aktima o njoj nema izravnih odredbi. Na svu sreću, postoje odredbe u člancima pojedinih akata koje na posredan način, negativnim definiranjem, što se ne smatra diskriminacijom, omogućuju njezino definiranje. Tako Međunarodna konvencija o ukidanju svih oblika rasne diskriminacije u članku 1. stavku 4. propisuje: "Posebne mjere, koje su donesene jedino u svrhu da se osigura odgovarajući napredak određenih rasnih ili etničkih skupina ili osoba kojima je nužna zaštita koja može biti potrebna radi jamčenja, uživanja i ostvarenja prava čovjeka i osnovnih sloboda pod jednakim uvjetima, ne smatraju se kao mjere rasne diskriminacije, pod uvjetom da nemaju za rezultat održanje različitih prava za razne rasne skupine i da se ne održavaju na snazi kada se postignu ciljevi radi kojih su te mjere bile poduzete."

Okvirna konvencija za zaštitu nacionalnih manjina u svom članku 4. stavku 2. utvrđuje mjere koje se ne smatraju aktom diskriminacije. Stavak 2. članka 4. glasi:

"Članice se obvezuju da usvoje, gdje je to potrebno, odgovarajuće mjere za unapređenje, u svim oblastima ekonomskog, socijalnog, političkog i kulturnog života, pune efektivne ravnopravnosti između pripadnika nacionalnih manjina i onih koji pripadaju većini. U tom pogledu će se voditi računa o posebnim uvjetima pripadnika nacionalnih manjina."

Hrvatski zakonodavac opredijelio se u Ustavnom zakonu o pravima nacionalnih manjina govoriti o "osiguranju i ostvarivanju posebnih prava i sloboda pripadnika nacionalnih manjina", što je propisano u članku 7. koji glasi: "Republika Hrvatska osigurava ostvarivanje posebnih prava i sloboda pripadnika nacionalnih manjina koja oni uživaju pojedinačno ili zajedno s drugim osobama koje pripadaju istoj nacionalnoj manjini, a kada je to određeno ovim Ustavnim zakonom ili posebnim zakonom, zajedno s pripadnicima drugih nacionalnih manjina, naročito:

1. služenje svojim jezikom i pismom, privatno i u javnoj uporabi, te u službenoj uporabi;

2. odgoj i obrazovanje na jeziku i pismu kojim se služe;

3. uporaba svojih znamenja i simbola;

4. kulturna autonomija održavanjem, razvojem i iskazivanjem vlastite kulture, te očuvanja i zaštite svojih kulturnih dobara i tradicije;

5. pravo na očitovanje svoje vjere te na osnivanje vjerskih zajednica zajedno s drugim pripadnicima te vjere;

6. pristup sredstvima javnog priopćavanja i obavljanja djelatnosti javnog priopćavanja (primanje i širenje informacija) na jeziku i pismu kojim se služe;

7. samoorganiziranje i udruživanje radi ostvarivanja zajedničkih interesa;

8. zastupljenost $\mathrm{u}$ predstavničkim tijelima na državnoj i lokalnoj razini, te u upravnim i pravosudnim tijelima;

9. sudjelovanje pripadnika nacionalnih manjina u javnom životu i upravljanju lokalnim poslovima putem vijeća i predstavnika nacionalnih manjina; 
10. zaštita od svake djelatnosti koja ugrožava ili može ugroziti njihov opstanak, ostvarivanje prava i sloboda."

Zakon o izmjenama i dopunama Zakona o suzbijanju diskriminacije, ${ }^{32} \mathrm{u}$ članku 9. stavku 2. propisuje: "(2) Iznimno od stavka 1. ovoga članka, ne smatra se diskriminacijom stavljanje u nepovoljniji položaj u sljedećim slučajevima:

1. kada je takvo postupanje određeno zakonom radi očuvanja zdravlja, javne sigurnosti, održavanja javnog reda i mira, prevencije kaznenih djela i zaštite prava i sloboda drugih ljudi te ako su upotrijebljena sredstva u demokratskom društvu primjerena i nužna za postizanje željenog cilja, pod uvjetom da takvo postupanje ne dovodi do izravne ili neizravne diskriminacije na osnovi rasne ili etničke pripadnosti, boje kože, vjere, spola, nacionalnog i socijalnog podrijetla, spolne orijentacije i invaliditeta;

2. posebnih mjera koje uključuju bilo koju mjeru privremene naravi, koja je nužna i prikladna za ostvarivanje stvarne jednakosti društvenih skupina koje su u nepovoljnijem položaju, na temelju neke od osnova iz članka 1. ovoga Zakona kada je takvo postupanje temeljeno na odredbama zakona, podzakonskog akta, programa, mjera ili odluka u cilju poboljšanja položaja etničkih, vjerskih, jezičnih ili drugih manjina ili drugih skupina građana ili osoba diskriminiranih po osnovama iz članka 1. stavka 1. ovoga Zakona;

3. provođenja mjera socijalne politike kojima se pogoduje osobama ili domaćinstvima težeg imovinskog ili socijalnog stanja pod uvjetom da takve mjere ne dovode do izravne ili neizravne diskriminacije na temelju spola, spolne orijentacije, rase, boje kože, etničke pripadnosti, vjerskog uvjerenja i invaliditeta;

4. u odnosu na određeni posao kad je narav posla takva ili se posao obavlja u takvim uvjetima da značajke povezane s nekom od osnova iz članka 1. ovoga Zakona predstavljaju stvarni i odlučujući uvjet obavljanja posla ako je svrha koja se time želi postići opravdana i uvjet odmjeren;

5. pri obavljanju profesionalnih aktivnosti, odnosno zasnivanju radnog odnosa, uključenju u članstvo te u djelovanju koje je u skladu s naukom i poslanjem crkve i vjerske zajednice upisane u Evidenciju vjerskih zajednica u Republici Hrvatskoj, te druge javne ili privatne organizacije čiji se sustav vrijednosti temelji na vjeri ili uvjerenju, a koja djeluje u skladu s Ustavom i zakonom, ako tako zahtijevaju vjerska doktrina ili uvjerenja, u slučaju kada zbog prirode tih aktivnosti ili okolnosti u kojima se obavljaju, vjera ili uvjerenje neke osobe predstavljaju istinski, zakonit i opravdan uvjet za obavljanje posla, uzimajući u obzir sustav vrijednosti te organizacije;

6. na temelju dobi pri ugovaranju premija osigurnina i drugih uvjeta u osiguranju na temelju općeprihvaćenih načela procjene rizika, u skladu s relevantnim i točnim statističkim podacima i pravilima aktuarske matematike; 
7. u pristupu dobrima, uslugama i sportu te pružanju istih ako je pristup dobru i/ili usluzi namijenjen isključivo ili prvenstveno pripadnicima jednog spola ili osobama s invaliditetom pod uvjetom da je takvo postupanje objektivno i razumno opravdano legitimnim ciljem te ako su upotrijebljena sredstva primjerena i nužna cilju koji se želi postići;

8. na osnovi dobi, ako je takvo postupanje objektivno i razumno opravdano legitimnim ciljem, uključujući legitimne ciljeve socijalne politike, socijalne i zdravstvene zaštite, politike zapošljavanja, promicanja ciljeva tržišta rada i stručnog osposobljavanja, te ako su sredstva za njegovo postizanje primjerena i nužna. Primjerice, diskriminacijom se ne smatra: određivanje najniže ili najviše dobi i/ili profesionalnog iskustva i/ili stupnja obrazovanja kao uvjeta za zasnivanje radnog odnosa ili kao uvjeta za stjecanje drugih pogodnosti vezanih za radni odnos; određivanje prikladne i primjerene najviše dobi kao razloga za prestanak radnog odnosa, a koja je sukladna uvjetima za stjecanje prava na starosnu mirovinu, propisivanje dobi ili razumnog razdoblja zaposlenja kao uvjeta za stjecanje ili ostvarivanje prava na mirovinu, ili drugog prava iz sustava socijalne sigurnosti, uključujući i područje socijalne skrbi, mirovinskog i zdravstvenog osiguranja te osiguranja za slučaj nezaposlenosti i određivanje dobi kao uvjeta za pristup obrazovanju ili određenim dobrima ili uslugama, pod uvjetom da su zadovoljeni uvjeti iz prve rečenice ove točke;

9. na temelju državljanstva prema posebnim propisima;

10. kod stavljanja u nepovoljniji položaj pri uređivanju prava i obveza uređenih Obiteljskim zakonom, a osobito u svrhu legitimne zaštite prava i dobrobiti djece, zaštite javnog morala i pogodovanja braku, pri čemu upotrijebljena sredstva moraju biti primjerena i nužna."

Iz citiranih odredbi nesporno proizlazi da one ne poznaju i ne upotrebljavaju načelo pod nazivom pozitivne diskriminacije. Inače naziv ovog načela povezan je s tzv. afirmativnom akcijom koji kao ideja odnosno načelo "potječe iz Sjedinjenih Država i označava privremene posebne mjere koje vlada poduzima s ciljem poduzimanja de facto jednakosti i ukidanju institucionalnih oblika diskriminacije". ${ }^{33}$

Načelo pozitivne diskriminacije i zbog toga što nije izrijekom pravnim aktima utvrđeno i kao takvo definirano ponekad se još naziva "pozitivnim mjerama", "preferencijalnim tretmanom", "afirmativnim djelovanjem", pa čak i "reverznom diskriminacijom". Različitost inačica koje se odnose na ovaj pojam sama po sebi upućuje na to da o sadržaju i obilježjima ovog pojma nije ni u doktrini, niti u zakonodavstvu, pa ni u jurisprudenciji postignuta suglasnost. Međutim, neovisno o neujednačenosti pristupa ovom pojmu i njegovoj mogućoj kontraverznosti, načelo pozitivne diskriminacije prihvaćeno je i kao pozitivne (poticajne i privremene) mjere ozakonjeno i to negativnim određenjem kada se one ne smatraju diskriminacijom. Za potrebe ovog rada ja ću navesti "svoju" definiciju pozitivne diskriminacije koju

33 "Razumijevanje ljudskih prava, Priručnik o obrazovanju za ljudska prava", str. 93., o.c. 
sam prije svega koristio u svezi s reguliranjem, ostvarivanjem i zaštitom prava i sloboda pripadnika nacionalnih manjina i njihovih kolektiviteta. Ja u tom kontekstu definiram "pozitivnu diskriminaciju kao raznovrsnost mjera i prava postupovne i materijalnopravne prirode, propisanih zakonom u skladu s ustavom, kojima se stvaraju povlastice odnosno privilegirani položaj i uvjeti za ostvarivanje prava i sloboda koji pripadaju nacionalnim manjinama i njihovim pripadnicima, a koje ne bi mogli ostvariti, neovisno o tome što su im osigurana objektivnim pravom, samo zato što su manjina, tj. zato što bi u odlučivanju i ostvarivanju tih prava bili onemogućeni načelom većine". ${ }^{34}$

Nastavno ću se samo baviti pitanjem pozitivne diskriminacije kod uređivanja, ostvarivanja i zaštite prava pripadnika nacionalnih manjina i njihovih asocijacija. To, dakako, ne znači da i u drugim područjima društvenih odnosa nema pozitivne diskriminacije koju je svojim pravnim propisima kad su u pitanju nacionalne manjine uredila $\mathrm{RH}^{35}$

Dapače, radi se o čitavoj lepezi takvih mogućih društvenih odnosa što je vidljivo i iz citiranog članka 9. stavak 2. Zakona o izmjenama i dopunama zakona o suzbijanju diskriminacije.

\section{POZITIVNA DISKRIMINACIJA I PRAVNA REGULACIJA PRAVA I SLOBODA PRIPADNIKA NACIONALNIH MANJINA U RH}

Radi izbjegavanja bilo kakvog diskrecijskog ponašanja koje bi imalo diskriminacijske posljedice po nacionalne manjine i njihove pripadnike zbog dominacije i supremacije većine u ustavnim demokratskim državama vladavine prava i ljudskih prava i temeljnih sloboda, unaprijed se pravnim propisima utvrđuju pozitivne mjere za ostvarivanje manjinskih prava i sloboda, a najmanje onih koja su neophodna za potvrđivanje, realiziranje i unapređivanje njihova ethosa. Te mjere nazivaju se pozitivna diskriminacija.

Republika Hrvatska svojim je Ustavom priznala status nacionalnih manjina svim pripadnicima koji se osjećaju kao pripadnici nekog entiteta. Preambula Ustava nabraja dvadeset dvije nacionalne manjine u Hrvatskoj, s time da i taj popis nije konačan, nego je riječima "i drugih" otvoren za nastavak bilo koje nacionalne manjine po nekom drugom entitetu koji još nije obuhvaćen. Dakako, ako se pojavi dostatan broj pripadnika neke nacionalne manjine koji se tako osjećaju i izjašnjavaju te se žele organizirati i djelovati kao nacionalna manjina u Hrvatskoj.

Ustav je nadalje člankom 15. zajamčio ravnopravnost pripadnicima svih nacionalnih manjina. Propisao je da se ravnopravnost i zaštita prava nacionalnih

34 Arlović, M., o.c., str. 289.

35 Potvrdu izložene teze najlakše je učiniti provjerom formalnopravnih izvora prava nacionalnih manjina. Ja sam ih u svojoj knjizi Pravo nacionalnih manjina u Republici Hrvatskoj izložio, te zainteresiranog čitatelja upućujem na njezine stranice od 293.-315., o. c. 
manjina uređuje ustavnim zakonom koji ima pravnu snagu organskog zakona. Osigurao je pozitivnu diskriminaciju omogućujući da se, pored općeg biračkog prava, zakonom može pripadnicima nacionalnih manjina osigurati posebno pravo da biraju svoje zastupnike u Hrvatski sabor. Zajamčio je svim pripadnicima nacionalnih manjina slobodno izražavanje nacionalne pripadnosti, slobodno služenje svojim jezikom i pismom i kulturnu autonomiju.

Osim toga, člankom 12. stavkom 2. Ustav je otvorio mogućnost da se zakonom može u lokalnim jedinicama u službenu upotrebu uvesti i drugi jezik te ćirilično pismo. Upotrebljava se izričaj drugi jezik jer je stavkom 1. istog članka propisano: "U Republici Hrvatskoj u službenoj je uporabi hrvatski jezik i latinično pismo". Prema tome, uvođenje drugog jezika i ćiriličnog pisma može biti u tim lokalnim jedinicama samo u službenoj i ravnopravnoj upotrebi s hrvatskim jezikom i latiničnim pismom. Nadalje, člankom 83. stavkom 1. propisano je: "Zakone (organski zakoni) kojima se uređuju prava nacionalnih manjina Hrvatski sabor donosi dvotrećinskom većinom glasova svih zastupnika".

Hrvatski sabor je za ostvarivanje jamstva iz članka 15., te mogućnosti iz članka 12. stavka 2. Ustava Republike Hrvatske donio sve potrebne zakone. Tako je donesen Ustavni zakon o pravima nacionalnih manjina, ${ }^{36}$ Zakon o uporabi jezika i pisma nacionalnih manjina u Republici Hrvatskoj, ${ }^{37}$ Zakon o odgoju i obrazovanju na jeziku i pismu nacionalnih manjina ${ }^{38}$ i Zakon o ratifikaciji Okvirne konvencije za zaštitu nacionalnih manjina. ${ }^{39} \mathrm{Uz}$ navedene ustavne norme ovi zakoni čine matični dio mjerodavnog prava uređenja, ostvarivanja i zaštite prava i sloboda nacionalnih manjina i njihovih pripadnika u Hrvatskoj. No, time nisu iscrpljeni svi formalnopravni izvori zakona i drugih propisa koji sadrže pojedine odredbe kojima se uređuju i štite prava i slobode nacionalnih manjina u Hrvatskoj. Njih je popriličan broj pa ih ovom prilikom neću nabrajati. Osim toga, za pozitivnu diskriminaciju odnosno pozitivne mjere sasvim su dostatni ovi koje smo nabrojali kao direktne zakone kojima se uređuju prava i slobode nacionalnih manjina. Čak štoviše, člankom 7. Ustavnog zakona o pravima nacionalnih manjina nabrojana su posebna "prava i sloboda pripadnika nacionalnih manjina koja oni uživaju pojedinačno ili zajedno s drugim osobama koje pripadaju istoj nacionalnoj manjini, a kada je to određeno ovim Ustavnim zakonom ili posebnim zakonom, zajedno s pripadnicima drugih nacionalnih manjina...". Svrstana su u grupe prava u okviru 10 točaka. Kod poimanja opsega i sadržaja ovih posebnih prava i sloboda pripadnika nacionalnih manjina treba imati u vidu, u najmanju ruku, dvije okolnosti. Prvo, sadržaj pojedinih točaka ovih posebnih prava i sloboda pripadnika nacionalnih manjina obuhvaća čitav splet društvenih odnosa, u koje stupaju ili se u njima već nalaze nacionalne manjine

\footnotetext{
36 Ustavni zakon o pravima nacionalnih manjina objavljen je u Narodnim novinama broj 155/02.

37 Zakon o uporabi jezika i pisma nacionalnih manjina u Republici Hrvatskoj objavljen je u Narodnim novinama broj 51/00. i 56/00. - ispravak.

38 Zakon o odgoju i obrazovanju na jeziku i pismu nacionalnih manjina objavljen je u Narodnim novinama broj 51/00. i 56/00. - ispravak.

39 Zakon o ratifikaciji Okvirne konvencije za zaštitu nacionalnih manjina objavljen je u Narodnim novinama - Međunarodni ugovori broj 14/97.
} 
i njihovi pripadnici s različitim pravima, obvezama, odgovornostima i slobodama. Konglomerat tih odnosa takav je da, u pravilu, traži donošenje posebnog zakona za njihovo uređivanje ili da se unutar pojedinih zakona koji takve odnose reguliraju u cijeloj društvenoj zajednici posvete posebni dijelovi kojim će se oni urediti. U praksi hrvatskog zakonodavca imamo dovoljno primjera za oba navedena oblika. Primjerice za uređivanje, ostvarivanje i zaštitu posebnih "prava i sloboda pripadnika nacionalnih manjina koja oni uživaju pojedinačno ili zajedno s drugim osobama" u odnosu na "služenje svojim jezikom i pismom, privatno i u javnoj uporabi, te u službenoj uporabi" (točka 1. stavka 1. članka 7.), donesen je poseban zakon i sl. S druge strane, kad su u pitanju njihova posebna prava i slobode na zastupljenost u predstavničkim tijelima na državnoj i lokalnoj razini, te u upravnim i pravosudnim tijelima, točka 8. stavka 1. članka 7., odredbe kojima se uređuju ova pitanja sadržane su u odgovarajućim člancima Ustavnog zakona o pravima nacionalnih manjina, te zakona kojim se uređuju izbori za: Hrvatski sabor, za odgovarajuća tijela jedinica lokalne i regionalne samouprave, Zakon o sudovima itd.

Drugo, iako se sve navedene točke u stavku 1. članka 7. Ustavnog zakona o pravima nacionalnih manjina odnose na posebna prava i slobode, po mom mišljenju sve propisane pozitivne mjere za njihovo ostvarivanje ne bi se mogle smatrati pozitivnom diskriminacijom. Naprosto stoga što mnoge od njih, iako se odnose na nacionalne manjine i njihove pripadnike kao podzastupljene grupe u društvu, ne sadrže bitne elemente da bi ih se moglo označiti pozitivnom diskriminacijom. Radi se o tome da one same po sebi ne bi mogle biti suprotne zabrani različitog postupanja jer ne koriste neki zabranjeni kriterij razlikovanja (isključivanje, ograničavanje ili favoriziranje bilo pojedinca ili skupine) kako bi postigle svoj cilj. Ove dvije napomene potrebno je imati u vidu osobito u provođenju postupaka u kojima se utvrđuje postojanje pozitivne diskriminacije, razlozi koji je opravdavaju, a napose da je ona opravdana, razumna, nužna i očekivana u demokratskom društvu jer njihovo postojanje opravdava legitimni cilj.

Prethodno navedeno jasno ukazuje da je pitanje pozitivne diskriminacije samo po sebi veoma složeno, te da je s političkopravnog aspekta jedno od onih koje spada u najosjetljivija pitanja. Tim više što se u društvenoj praksi pozitivna diskriminacija (i to ne samo prema nacionalnim manjinama i njihovim pripadnicima već i prema drugim podzastupljenim skupinama u društvu), poistovjećuje s mjerama kojima se nacionalnim manjinama i njihovim pripadnicima daje i osigurava određena korist odnosno prednost u ostvarivanju prava te u drugim postupanjima u odnosu na većinsku skupinu. Klasični primjeri na kojima se temelji ovakva praksa u društvu jesu pozitivna diskriminacija pri zapošljavanju ili predodređenost određenog broja zastupničkih mjesta (kvote) prilikom izbora predstavnika nacionalnih manjina u predstavnička tijela na lokalnoj, regionalnoj i državnoj razini. Takve prigovore mora se u startu odbiti kao neosnovane i neutemeljene. Prvo iz razloga što u demokratskim društvima koja počivaju na donošenju odluka većinom, podzastupljene grupe ne mogu doći u poziciju da imaju većinu za izglasavanje svojih posebnih prava i sloboda i na načelu pozitivne diskriminacije. Bit će uvijek preglasane. Drugo, u demokratskom društvu te mjere kao posebna prava i slobode 
za podzastupljene grupe (uključivo nacionalne manjine i njihove pripadnike) ozakonjuje donošenjem i provedbom odgovarajućih zakona većina. Takvim svojim postupanjem ili nepostupanjem većina daje osnovu za procjenu u kojoj mjeri ona ostvaruje demokratske vrednote, standarde, ideale i ciljeve. Treće, vladajuće većine zbog toga kod ozakonjenja pozitivnih diskriminacija vode računa o tome da one moraju biti dopuštene u demokratskom društvu, da su pravno (zakonom) uređene, da ne narušavaju ljudska prava i temeljne slobode drugih (uključivo i pripadnika drugih nacionalnih manjina) odnosno da su razmjerne, nužne i opravdane, te da su u odnosu na društvenu skupinu za koju se donose jednake i dakako da su vremenski privremene. $S$ tim da se privremenost procjenjuje realnim potrebama njihova egzistiranja jer bez njih nacionalne manjine i njihovi pripadnici ne bi mogli ostvarivati svoja manjinska prava i slobode, ne narušavajući i ugrožavajući ljudska prava i temeljne slobode drugih. Upravo stoga u postupanju i ostvarivanju zaštite prava i sloboda nacionalnih manjina i njihovih pripadnika unutar Republike Hrvatske u ustavnosudskim sporovima ima nadležnost Ustavni sud Republike Hrvatske.

\section{USTAVNI SUD REPUBLIKE HRVATSKE U POSTUPCIMA OPRAVDANOSTI PRIMJENE NAČELA POZITIVNE DISKRIMINACIJE}

Ustavni sud Republike Hrvatske ima izvornu ustavnu nadležnost u pružanju zaštite prava i sloboda nacionalnih manjina i njihovih pripadnika općenito pa tako i kada se reguliraju, ostvaruju i štite temeljem primjene načela pozitivne diskriminacije. Ova njegova nadležnost proizlazi iz više točaka propisanih Ustavom RH, od onih koje podvodimo pod apstraktnu kontrolu ustavnosti i zakonitosti, pa sve do konkretnih sporova radi zaštite ljudskih prava i temeljnih sloboda na osnovi ustavne tužbe, te nadzora ustavnosti i zakonitosti izbora i državnog referenduma te rješavanja izbornih sporova koji nisu u nadležnosti sudova.

Obavljajući svoju nadležnost postupanjem u ovim predmetima, Ustavni sud Republike Hrvatske izgrađivao je svoju praksu kako u predmetima u kojima je pored ostalog ocjenjivao postojanje i/ili ne postojanje zabranjene diskriminacije, tako i u predmetima u kojima je propitivao i ocjenjivao postojanje pozitivne diskriminacije. Svoja stajališta Ustavni sud Republike Hrvatske gradio je u postupcima ocjenjivanja postojanja pozitivne diskriminacije u predmetima apstraktne kontrole ustavnosti i zakonitosti i u pojedinačnim predmetima u kojima je postupao radi zaštite ustavom zajamčenih ljudskih (i manjinskih) prava i temeljnih sloboda na temelju podnesenih ustavnih tužbi. Postupajući u tim predmetima, iskristaliziralo se jedno, gotovo neupitno pravilo. Ako bismo ga htjeli odrediti, ono bi moglo glasiti: na temelju istih vrednota, načela, mjerila i kriterija utvrđuje se postojanje kako diskriminacije koja je zabranjena tako i pozitivne diskriminacije. Specifična razlika između njih povezana je s odgovorom na pitanje da je pozitivna diskriminacija dopuštena jer ima objektivno opravdanje, nužna u demokratskom društvu i razmjerna za ostvarivanje 
legitimnog cilja. Dakako, u dokazivanje njezina objektivnog opravdanja potrebno je provesti testove koji će utvrditi da je ona zakonski uređena i dopuštena jer je za njeno zakonodavno propisivanje zakonodavac imao legitimni cilj, zatim da je nužna i prikladna mjera za ostvarenje legitimnog cilja te da mu je razmjerna, odnosno da ne postoji neka druga lakša mjera primjenom koje bi se mogao ostvariti na jednako kvalitetan način legitimni cilj.

Postupajući u predmetima apstraktne ocjene ustavnosti zakona polazeći od navedenih načela, mjerila i kriterija, Ustavni je sud Republike Hrvatske zauzeo stajalište da: "članak 14. Ustava ne zabranjuje zakonodavcu da prava i obveze pojedinih istovrsnih ili sličnih skupina uređuje različito, ako se time ispravljaju postojeće nejednakosti među tim skupinama ili za to postoje drugi opravdani, na Ustavu utemeljeni razlozi.

Različito uređenje prava i obveza, međutim, smatrat će se diskriminirajućim ako propisano razlikovanje nema objektivnog i razumnog opravdanja, odnosno ako se time ne ostvaruje legitimni cilj ili ako ne postoji razmjernost između propisane zakonske mjere i cilja koji se nastoji postići."

U istoj je odluci ${ }^{40}$ Ustavni sud utvrdio da je "zakonodavac slobodan procijeniti opravdava li različitost i u kojoj mjeri, u inače sličnim situacijama, različito uređenje prava i obveza, pri čemu opseg njegovih ovlasti ovisi o predmetu zakonskog uređenja i s njim povezanim činjenicama i okolnostima. U pravilu bi morali postojati vrlo jaki ustavnopravno prihvatljivi razlozi da bi Ustavni sud ocijenio suglasnim s Ustavom različitost zakonskog uređenja koje se temelji isključivo na razlici u osobinama navedenim u članku 14. stavku 1. Ustava."41

Polazeći od svojih zauzetih stajališta, Ustavni sud Republike Hrvatske proveo je postupak ocjene ustavnosti članka 74. stavaka 7. i 8. Zakona o sudovima (Narodne novine broj 150/05., 16/07. i 113/08.).

Navedene odredbe Zakona o sudovima odnose se na pitanje imenovanja sudaca te na to da se prilikom imenovanja sudaca "mora voditi računa o zastupljenosti sudaca pripadnika nacionalnih manjina, sukladno odredbama Ustavnog zakona o pravima nacionalnih manjina", (stavak 7. članka 74.), nadalje da "kada pripadnici nacionalnih manjina podnose prijavu na objavljeno slobodno sudačko mjesto, imaju se pravo pozivati na ostvarivanja prava koja im pripadaju sukladno odredbama Ustavnog zakona o pravima nacionalnih manjina" (stavak 8. članka 74.).

Ustavni sud utvrdio je da prijedlog nije osnovan te je donio Rješenje broj: U-I2767/2007 na svojoj sjednici od 31. ožujka 2009. g. o neprihvaćanju prijedloga za pokretanje postupka za ocjenu suglasnosti s Ustavom članka 74. stavaka 7. i 8. Zakona o sudovima.

40 Riječ je o odluci Ustavnog suda Republike Hrvatske broj: U-I-764/2004, U-I-2578/2004;

U-I-2670/2004; U-I-3006/2004 i U-I-1452/2005 od 25. ožujka 2007. g. (Narodne novine broj 34/07.).

${ }_{41}$ Navedena stajališta Ustavni je sud opetovano ponovio u svojoj Odluci broj: U-I-1152/2000, U-I1814/2001, U-I-1478/2004, U-I-3137/2004, U-I-3760/2005 od 18. travnja 2007. (Narodne novine broj 43/07.). 
Obrazlažući svoje rješenje, pored ostaloga naveo je i sljedeće:

"4. Polazeći, dakle, od navedenih odredaba Ustava, Okvirne konvencije, Ustavnog zakona o pravima nacionalnih manjina zakonodavac je, temeljem ovlasti propisane člankom 2. stavkom 4. alinejom 1. Ustava, a razrađujući svoju ustavnu ovlast za uređenje gospodarskih, pravnih i političkih odnosa u Republici Hrvatskoj, bio ovlašten propisati pravo pripadnicima nacionalnih manjina na njihovu zastupljenost i u pravosudnim tijelima.

Naime, provodeći ustavno opredjeljenje i preuzete međunarodne obveze osporenim odredbama članka 74 . ZS-a, pripadnicima nacionalnih manjina osigurava se zastupljenost u pravosudnim tijelima na razini na kojoj je ustrojeno pravosudno tijelo, a prednost pod istim uvjetima u popunjavanju mjesta $\mathrm{u}$ navedenom tijelu imaju predstavnici nacionalnih manjina.

Navedena prednost predstavlja posebnu pozitivnu mjeru, koja podrazumijeva namjerno davanje prednosti određenoj skupini ili skupinama (etnička, spolna, socijalna, politička, dobna i dr.) s ciljem otklanjanja stvarne nejednakosti i razlikovanja osoba po navedenim i drugim osobinama te se na taj način sprečavaju različiti oblici otvorene (direktne) ili prikrivene (indirektne) diskriminacije ako zakonodavac utvrdi da je ona prisutna u odnosu na njih.

Propisana prednost pri zapošljavanju pripadnika nacionalnih manjina, $u$ konkretnom slučaju, međutim, nije automatska i bezuvjetna i primjenjuje se samo uz ispunjavanje propisanih uvjeta, a njezinom primjenom osigurava se ravnomjernost u zastupljenosti pripadnika nacionalnih manjina u pravosudnim tijelima, na način kojim se osigurava njihov ravnopravan položaj s ostalim građanima Republike Hrvatske.

Stoga, prednost pri zapošljavanju, kako je to propisano osporenim odredbama stavaka 7. i 8. članka 74. ZS-a, valja promatrati kao posebnu pozitivnu mjeru u korist pripadnika nacionalnih manjina, s ciljem da se pripadnicima nacionalnih manjina (manjinske skupine) omogući učinkovito sudjelovanje u javnim poslovima kroz zapošljavanje i u pravosudnim tijelima, u smislu članka 4. stavaka 2. i 3. i članka 15. Okvirne konvencije.

Propisivanje navedene pozitivne mjere pri zapošljavanju pripadnika nacionalnih manjina ulazi u područje slobodne prosudbe zakonodavca i ima se smatrati opravdanom i dopuštenom sve dok traju razlozi zbog kojih je uvedena, o čemu u prvom redu odlučuje zakonodavac, odnosno sve dok se njome ne vrijeđa načelo razmjernosti, propisano člankom 16. Ustava, što je u prvom redu predmet ustavnosudske kontrole.

Stoga, sve dok se pozitivna mjera, propisana člankom 22. Ustavnog zakona, može ocijeniti opravdanom, dopuštenom i razmjernom, ona se neće smatrati diskriminacijom zabranjenom člankom 14. stavkom 2. Ustava, kako to pogrešno shvaća predlagateljica."42

42 Rješenje Ustavnog suda Republike Hrvatske broj: U-I-2767/2007 od 31. ožujka 2009. 
Citiranom dijelu obrazloženja navedenog rješenja Ustavnog suda nema se što dodati. Ono je potpuno jasno i utemeljeno na valjanom tumačenju ove pozitivne diskriminacije koju dopušta i pravno uređuje ustavnopravni sustav Hrvatske. No, prilika je ukazati da se iz citiranog dijela (stavak 3.) obrazloženja vidi da Ustavni sud Republike Hrvatske prati i praksu ESLJP-a i praksu Europskoga suda pravde te njihova stajališta prihvaća kao svoja. ${ }^{43}$

Kad je u pitanju ova pozitivna (mjera) diskriminacija u korist pripadnika nacionalnih manjina, zauzeta svoja stajališta Ustavni sud Republike Hrvatske dosljedno primjenjuje i u konkretnim predmetima zaštite ljudskih prava i temeljnih sloboda koje pokreću pojedinci podnoseći ustavnu tužbu smatrajući da im je konačnim aktom državnih $\mathrm{i} / \mathrm{ili}$ drugih tijela $\mathrm{s}$ javnim ovlastima povrijeđeno njihovo pravo i sloboda.

Tako je npr. u odbijajućoj Odluci broj: U-III-1286/2012 od 11. prosinca 2014. g. Ustavni sud o prijedlogu podnositelja odlučio odbivši ustavnu tužbu jer: "članak 22. stavak 4. UZPNM-a, kojim je propisana prednost pri zapošljavanju predstavnika nacionalnih manjina, predstavlja posebnu pozitivnu mjeru zakonodavca kojoj je cilj osiguranje ravnomjerne zastupljenosti pripadnika nacionalnih manjina $i$ u pravosudnim tijelima te se na taj način osigurava njihov ravnopravan položaj s ostalim građanima Republike Hrvatske. Međutim, navedena prednost pri zapošljavanju nije automatska i bezuvjetna, već je za njezinu primjenu potrebno da su prethodno ispunjeni tim zakonima propisani uvjeti." ${ }^{44}$

Dosljednost postupanja u skladu sa svojim stajalištima Ustavni sud Republike Hrvatske svjedoči i kod postupanja i odlučivanja o opravdanosti, odnosno neopravdanosti pozitivne diskriminacije glede upotrebe jezika i pisma nacionalnih manjina u Republici Hrvatskoj. Tako je postupio prilikom apstraktne kontrole ustavnosti i zakonitosti i u predmetu broj: U-II-6110/2013 o kojem je odlučio na svojoj plenarnoj sjednici 12. kolovoza 2014. godine, izrekom koja glasi:

"I. Ukida se članak 22. Statutarne odluke o izmjenama i dopunama Statuta Grada Vukovara, klasa: 012-03/09-01/01, urbroj: 2196/01-01-13-31 od 4. studenoga 2013. ("Službeni vjesnik Grada Vukovara" broj 7/13.), koju je donijelo Gradsko vijeće Grada Vukovara.

\section{Ova odluka objavit će se u 'Narodnim novinama'."}

Sažeto bi se obrazloženje moglo izraziti u sljedećem tekstu: "Prema članku 12. stavku 2. Ustava u pojedinim lokalnim jedinicama uz hrvatski jezik i latinično pismo u službenu se uporabu može uvesti i drugi jezik te ćirilično ili koje drugo pismo pod uvjetima propisanima zakonom".

Gradsko je vijeće osporenom odredbom statutarne odluke propisalo: "područje Grada Vukovara se u cijelosti izuzima od primjene odredaba Zakona o uporabi

43 Predmet C-450/93 Eckhard Kalanke v Freie Hansestadt Bremen (1995.) ECR I-03051, te ESLJP presuda Willis protiv Ujedinjenog Kraljevstva, zahtjev broj 36042/97, § 48.

44 Izbor Odluka Ustavnog suda Republike Hrvatske za 2014. g., izdanje Narodnih novina, Zagreb, 2015., str. 306 . 
jezika i pisma nacionalnih manjina u RH te od članka 12. UZoPNM do ispunjenja uvjeta iz članka 8. UZoPNM.

\section{(...)}

Ustavni sud nije smatrao potrebnim posebno razmatrati je li Gradsko vijeće Grada Vukovara uvelo srpski jezik i ćirilično pismo u službenu uporabu u Gradu Vukovaru još Statutom iz 2009., kada nije postojala zakonska obveza iz članka 12. stavka 1. UZoPNM-a da to učini s obzirom da u to vrijeme udjel srpske nacionalne manjine u ukupnom stanovništvu Grada Vukovara nije prelazio jednu trećinu.

Nije smatrao potrebnim posebno obrazlagati ni razloge zbog kojih je članak 22. Statutarne odluke iz 2013. nesuglasan s Ustavom. Ocijenio ih je očitim. U tom smislu smatrao je dostatnim utvrditi da prihvaća stajališta Vlade Republike Hrvatske." 45

U području djelovanja ove pozitivne diskriminacije Ustavni je sud odlučivao i u predmetu broj: U-VIIR-4640/2014 na svojoj sjednici od 12. kolovoza 2014. g. Radi se o referendumskom pitanju, odnosno o tome je li ono u suglasnosti s Ustavom. U tom predmetu Ustavni sud odlučio je:

"I. Utvrđuje se da nije u skladu s Ustavom referendumsko pitanje predloženo u zahtjevu za raspisivanje referenduma Građanske inicijative 'Stožer za obranu hrvatskog Vukovara', koji je njezin Organizacijski odbor dostavio predsjedniku Hrvatskog sabora 13. prosinca 2013. i koji je u Hrvatskom saboru zaveden pod ur. brojem: 361-13-03-1787, klasa: 014-01/13-01/06, a koje glasi:

'Jeste li za to da se članak 12. stavak 1. Ustavnog zakona o pravima nacionalnih manjina ('Narodne novine', br. 155/02., 47/10., 80/10. i 93/11.) mijenja tako da glasi: 'Ravnopravna službena uporaba jezika i pisma kojim se služe pripadnici nacionalne manjine ostvaruje se na području jedinice lokalne samouprave, državne uprave i pravosuđa, kada pripadnici pojedine nacionalne manjine čine najmanje polovinu stanovnika takve jedinice.'?'.

II. O predloženom referendumskom pitanju iz točke I. ove izreke nije dopušteno raspisivanje referenduma.

III. Na temelju članka 35. stavaka 4. i 5. Ustavnog zakona o Ustavnom sudu Republike Hrvatske ('Narodne novine' broj 99/99., 29/02. i 49/02. - pročišćeni tekst), Ustavni sud Republike Hrvatske određuje:

- da je Gradsko vijeće Grada Vukovara dužno u roku od jedne godine od dana objave ove odluke u 'Narodnim novinama', vodeći se člankom 6 . Zakona o službenoj uporabi jezika i pisma nacionalnih manjina ('Narodne novine' broj 51/00. i 56/00. - ispr.), a u duhu članka 8. Ustavnog zakona o pravima nacionalnih manjina ('Narodne novine' broj 155/02., 47/10. - odluka USRH, 80/10. i 93/11. - odluka USRH), u Statutu Grada Vukovara izrijekom propisati i urediti, za cijelo područje odnosno za pojedini dio ili pojedine dijelove područja Grada Vukovara, individualna prava pripadnika nacionalnih

45 Isto, str. 110 
manjina na službenu uporabu svoga jezika i pisma te javnopravne obveze tijela državne i javne vlasti između onih navedenih u Zakonu o službenoj uporabi jezika i pisma nacionalnih manjina ('Narodne novine' broj 51/00. i 56/00. - ispr.) za koje smatra da odgovaraju životnim činjenicama i faktičnim okolnostima u Gradu Vukovaru, u opsegu koji ne ugrožava samu bit tih prava, a istodobno uvažava potrebe većinskog hrvatskog naroda koje izviru iz još uvijek živih posljedica velikosrpske agresije početkom 90-ih godina 20. stoljeća te potrebu pravednog i pravilnog tretmana srpske nacionalne manjine na području Grada Vukovara;

- da je Vlada Republike Hrvatske dužna u roku od jedne godine od dana objave ove odluke u 'Narodnim novinama' uputiti u parlamentarnu proceduru izmjene i dopune Zakona o službenoj uporabi jezika i pisma nacionalnih manjina ('Narodne novine' broj 51/00. i 56/00. - ispr.) u kojima će urediti prikladan pravni mehanizam za slučajeve kad predstavnička tijela jedinica lokalne samouprave ne provode obveze iz Zakona o službenoj uporabi jezika i pisma nacionalnih manjina ('Narodne novine' broj 51/00. i 56/00. - ispr.) odnosno opstruiraju njegovu provedbu;

- da u razdoblju do donošenja izmjena i dopuna Zakona o upotrebi jezika i pisma nacionalnih manjina ('Narodne novine' broj 51/00. i 56/00. - ispr.) nadležna državna tijela neće provoditi taj zakon na području Grada Vukovara uporabom prisilnih mjera.

IV. Na temelju članka 35. stavaka 4. i 5. Ustavnog zakona o Ustavnom sudu Republike Hrvatske ('Narodne novine' broj 99/99., 29/02. i 49/02. - pročišćeni tekst), Ustavni sud Republike Hrvatske određuje:

- svaki budući zahtjev za raspisivanje referenduma koji Hrvatskom saboru bude podnesen na temelju članka 87. stavka 3. Ustava mora sadržavati detaljan prikaz činjenica i okolnosti koje su bile povod za referendumsko pitanje u predloženom sadržaju te dostatno i relevantno obrazloženje razloga zbog kojih se traži raspisivanje referenduma.

V. Ova odluka objavit će se u 'Narodnim novinama'."

Relativno opširno i detaljno obrazloženje ove odluke moglo bi se prepričati i u kraćoj sentenci izreći riječima:

"Individualno pravo pripadnika nacionalnih manjina na slobodu služenja svojim jezikom i pismom, za koja hrvatski Ustav smatra da čine samu bit identiteta nacionalnih manjina u Republici Hrvatskoj, od hrvatskog naroda, kao većinskog, zahtijeva toleranciju i razumijevanje, traži stalno podsjećanje na vrijednosti Ustava i na granice dopuštenog ponašanja prema manjinama, koje postavlja Ustav.

\section{(...)}

Predloženo povećanje praga za službenu uporabu jezika i pisma proteže se na sve nacionalne manjine u Republici Hrvatskoj, a prostorno obuhvaća sve općine i gradove na državnom teritoriju. Takav generalni zahvat nacionalnih 
dimenzija u već postignuti prag za službenu uporabu jezika i pisma, koji čine samu bit identiteta nacionalnih manjina u Republici Hrvatskoj, mora imati svoju jasnu i racionalnu osnovu te objektivno opravdanje. To znači da povećanje praga mora imati jasno izražen legitimni cilj u javnom/općem interesu, a mora biti i nužno u demokratskom društvu, to jest strogo razmjerno legitimnom cilju koji se nastoji postići. Drugim riječima, mora postojati prijeka društvena potreba za povećanjem postojećeg praga." 46

Sljedeći primjer ustavnosudskog postupanja Ustavnog suda Republike Hrvatske glede pozitivne diskriminacije vezan je uz primjenu ovog načela na izbore predstavnika nacionalnih manjina.

Ustavni sud Republike Hrvatske svojom je Odlukom broj: U-I-120/2011 i dr. od 29. srpnja 2011. godine odlučio o ustavnosti Zakona o izmjenama i dopunama Zakona o izborima zastupnika u Hrvatski sabor (Narodne novine broj 145/10.). U toj Odluci odlučio je:

"I. Pokreće se postupak za ocjenu suglasnosti s Ustavom te se ukidaju članak 1., članak 5., članak 6., članak 7., članak 8., članak 9. i članak 10. Zakona o izmjenama i dopunama Zakona o izborima zastupnika u Hrvatski sabor ('Narodne novine' broj 145/10.).

II. Do uređenja pitanja, sadržanih u ukinutim člancima iz točke I. ove izreke, u skladu s ustavnim zahtjevima obrazloženim u ovoj odluci, primjenjuju se mjerodavna pravila iz Zakona o izborima zastupnika u Hrvatski sabor ('Narodne novine' broj 116/99., 109/00., 53/03., 69/03. - pročišćeni tekst, 167/03., 44/06., 19/07. i 20/09.).

III. Ova odluka objavit će u 'Narodnim novinama'."

Sentenca obrazloženja ove odluke glasi: "Svrha pozitivnih mjera za nacionalne manjine u izbornim postupcima osiguravanje njihove zastupljenosti u Hrvatskom saboru radi integracije manjina u politički život zemlje, što isključuje njihovu instrumentalizaciju u druge svrhe (primjerice, za dobivanje većeg broja zastupničkih mandata radi osiguravanja odgovarajuće pozicije u parlamentu i izvršnoj vlasti)."47

Radi boljeg razumijevanja ove pozitivne diskriminacije treba imati u vidu da je Republika Hrvatska kod izbora zastupnika u Hrvatski sabor iz reda nacionalnih manjina prihvatila tzv. kvotni sustav njihove reprezentacije. U kvotni sustav, pored ostalog, pripada i tehnika unaprijed rezerviranih mjesta u Hrvatskom saboru. Hrvatska je ovu pozitivnu mjeru (diskriminaciju) prihvatila izražavajući njome svoj ustavnopravni cilj: da se manjinske skupine integriraju u politički život zemlje jer bi u protivnom bile izložene očitom riziku političke diskriminacije.

Polazeći od toga ustavnopravnog cilja, nesporno je da je ova pozitivna diskriminacija objektivno potrebna, nužna u demokratskom društvu, srazmjerna legitimnom cilju, ali do razine kojom zastupljenost nacionalnih manjina u

46 Isto, str. 329.-331.

47 Izbor Odluka Ustavnog suda Republike Hrvatske za 2011. g., izdanje Narodne novine, Zagreb, 2012. g., str. 72.-73. 
Hrvatskom saboru omogućuje: a) zastupljenost svih nacionalnih manjina, b) aktivno sudjelovanje u političkom životu i to tako da prije svega u zakonodavnim postupcima vode računa o tome da se prava i slobode nacionalnih manjina i njihovih pripadnika urede i zaštite u skladu s najvišim standardima koje omogućuju hrvatski Ustav i Okvirna konvencija itd. No, zahtjevi iznad ovih objektivnih i potrebnih prava i sloboda kao nužnih i opravdanih, smatraju se takvima koji prelaze okvire što ih daje navedena pozitivna diskriminacija te se kao mjere diskriminiranja većine smatraju nedopuštenima. Stoga je u konkretnom ustavnosudskom postupanju i odlučivanju Ustavni sud Republike Hrvatske donio navedenu citiranu odluku.

\section{ZAKLJUČAK}

Ljudskim pravima i temeljnim slobodama koje uključuju prava pripadnika nacionalnih (i drugih) manjina nadnacionalno i unutrašnje pravo pristupa kao jednoj od najviših vrednota demokratskog društva vladavine prava, a s druge strane kao bitnom konstitutivnom elementu na kojem moderni ustavi konstitucionaliziraju moderne ustavne demokratske države. Njihovo uređivanje, ostvarivanje i zaštita temelje se primarno na načelima jednakosti, ravnopravnosti, razmjernosti i zabrani diskriminacije. Zabrana diskriminacije je zapravo odlučujuće načelo koje jamči jednakost i ravnopravnost svakom ljudskom biću u pristupu i ostvarivanju ljudskih prava i temeljnih sloboda, te njihovu zaštitu u slučaju osporavanja i/ili ugrožavanja.

Međutim, prisutna svijest o slabostima demokratskog procesa u demokratskim društvima koja proizlazi iz načela da se odluke donose većinom glasova, realno manjine dovodi u poziciju da budu preglasane i u podređenom položaju u odnosu na većinu. Donositelji pravnih propisa radi izbjegavanja i prevladavanja takvih situacija koje rezultiraju povredom individualnih i kolektivnih prava pripadnika manjina, morali su posegnuti za korektivnim načelom. Takvo načelo pronađeno je u obliku i sadržaju pozitivne diskriminacije, odnosno tzv. pozitivnih mjera koje se iskazuju kao posebna prava i slobode manjina i njihovih pripadnika u odnosu prema većini i/ili međusobno. Pozitivna diskriminacija također je diskriminacija. No, ona nije zabranjena, ne samo zbog svog naziva "pozitivna" već zbog toga što za njezino postajanje egzistiraju objektivni i opravdani razlozi i potrebe, koji su razmjerni legitimnom cilju te nužni i legitimni radi njegova ostvarivanja. Temeljni legitimni cilj u pravilu se utvrđuje pravnim propisima višega ranga (zakonima, ustavnim zakonima pa i samim Ustavom) radi jamčenja pravne i stvarne mogućnosti da manjine i njihovi pripadnici ostvare ljudska prava i slobode, ali tako da, ostvarujući ih, istovremeno ne dovode druge u nejednak i neravnopravan položaj u ostvarivanju ljudskih prava i sloboda.

Navedena načela, uvjeti i kriteriji koji opravdavaju postojanje pozitivne diskriminacije istovremeno su i ključni elementi na kojima je moguće, i s pomoću kojih se mora, provesti diferenciranje pozitivne od svakog tipa direktne i/ili indirektne zabranjene diskriminacije. 
Zbog toga je problematika povezana uz priznanje postojanja pozitivne diskriminacije u ustavnopravnim porecima iznimno složeno i osjetljivo ne samo pravno, već i socijalno, ekonomsko pa i političko pitanje. No, s druge strane, ona izražava spremnost društva da je kao jedan od svojih ustavnopravnih ciljeva prihvati i kao instrument kojim većina tolerantno i s razumijevanjem stvara uvjete manjini za ostvarivanje njihovih bitnih ljudskih prava i sloboda.

Kod većine država, pa tako i u Republici Hrvatskoj, u različitim oblicima formalnopravnog manifestiranja i realnog ostvarivanja najčešće se pozitivna diskriminacija sreće kod uređivanja, ostvarivanja i zaštite ljudskih prava i sloboda nacionalnih manjina i njihovih pripadnika.

Ustavni sud Republike Hrvatske na nacionalnoj je razini konačno tijelo koje u postupcima apstraktne kontrole ustavnosti i zakonitosti te $\mathrm{u}$ konkretnim predmetima u povodu ustavne tužbe kontrolira ustavnost i zakonitost pozitivnih diskriminacija te na osnovi njih propisanih i zaštićenih ljudskih prava i sloboda manjina i njihovih pripadnika. U svojoj praksi on je izgradio stajališta koja su kompatibilna u sličnim i/ili istovrsnim predmetima sa stajalištima ESLJP-a ili Suda pravde EU-a.

Na kraju ovoga rada s nekoliko smo primjera pokazali kako i na koji način u predmetima s pozitivnom diskriminacijom postupa i odlučuje Ustavni sud Republike Hrvatske.

\section{LITERATURA}

1. Arlović, M.; Pravo nacionalnih manjina u Republici Hrvatskoj, Novi informator, Zagreb, 2015.

2. Bačić, A.; "Konstitucionalizam u transformaciji", Zbornik radova PF-a Split, br. 1-2/1999.

3. Barić Punda, V.; "Načelo nediskriminacije - jedno od temeljnih načela zaštite ljudskih prava i sloboda", Zbornik radova PF-a Split, br. 1-2/2005.

4. Costas, D.; Ljudska prava i imperija, Beograd, 2008. (reprint 2009.).

5. Crnić-Grotić, V.; "Zaštita manjina u okviru Vijeća Europe", Vladavina prava, br. 3-4/1999.

6. Čačić-Kumpes, J. i Kumpes, J.; "Etničke manjine: elementi definiranja i hijerarhizacija prava na razliku", Institut za migracije i narodnosti, Zagreb, Migracijske i etničke teme, 21 (2005.) br. 3.

7. Grupa autora (Grgić, A., Potočnjak, Ž., Rodin, S., Selanec, G., Šimonović Einwalter, T. i Uzelac, A.); Vodič uz Zakon o suzbijanju diskriminacije, Ured za ljudska prava Vlade Republike Hrvatske, Zagreb, 2009.

8. Guastini, R.; Sintaksa prava, Mlada Breza, Zagreb, 2016.

9. Kazaić, V.; "Prava manjina", Zbornik PF-a Mostar, vd. XII/1999.

10. Hrženjak, J.; Međunarodni i europski dokumenti o ljudskim pravima, Informator, Zagreb, 1992. 
11. Kymlicka, W.; Multikulturalno građanstvo: Liberalna teorija manjinskih prava, Naklada Jesenski i Turk, Zagreb, 2003.

12. Omejec, J.; "Granice ovlasti Ustavnog suda u postupku ocjene suglasnosti zakona s Ustavom", Zbornik PF-a Zagreb, br. 6/2003.

13. Politička enciklopedija, Beograd, 1976.

14. Pravni leksikon, Zagreb, 2007.

15. Priručnik o obrazovanju za ljudska prava: Razumijevanje ljudskih prava, izdavač Mreža za ljudska prava i Europski centar za izobrazbu i istraživanje o ljudskim pravima i demokraciji, Graz, 2003.

16. Radbruch, G.; Filozofija prava, Beograd, 1980.

17. Smerdel, B. i Sokol, S.; Ustavno pravo, Zagreb, 2006.

18. Tatalović, S.; "Nacionalne manjine i hrvatska demokracija", Politička misao, Zagreb, Vol. XLIII, (2006.) broj 2.

19. Tatalović, S.; "Regionalna suradnja i zaštita nacionalnih manjina", Međunarodne studije, god. V., br. 3/2005.

20. Ustavni sud Republike Hrvatske: Izbor odluka za 2011., Narodne novine, Zagreb, 2012.

21. Ustavni sud Republike Hrvatske: Izbor odluka za 2014., Narodne novine, Zagreb, 2015.

22. Ustavni sud Republike Hrvatske

- Odluka broj: U-I-U-I-764/2004, U-I-2578/2004; U-I-2670/2004; U-I-3006/2004 i

U-I-1452/2005 od 25. ožujka 2007. (Narodne novine broj 34/07.).

- Odluka broj: U-I-1152/2000, U-I-1814/2001, U-I-1478/2004, U-I-3137/2004, U-I-

3760/2005 od 18. travnja 2007. (Narodne novine broj 43/07.)

- Rješenje broj: U-I-2767/2007 od 31. ožujka 2009.

23. Europski sud pravde, predmet Eckhard Kalanke v Freie Hansestadt Bremen (1995.) ECR I-03051.

24. Europski sud za ljudska prava, predmet Willis protiv Ujedinjenog Kraljevstva, broj 36042/97.

25. Povelja Ujedinjenih naroda (Narodne novine - Međunarodni ugovori broj 15/93.).

26. Opća deklaracija o pravima čovjeka (usvojena na Općoj skupštini OUN-a, 10. prosinca 1948.).

27. Međunarodni pakt o građanskim i političkim pravima (Narodne novine-Međunarodni ugovori broj 12/93., 7/95. i 11/95.).

28. Međunarodni pakt o ekonomskim, socijalnim i kulturnim pravima (Narodne novine - Međunarodni ugovori broj 12/93.).

29. Međunarodna Konvencija o ukidanju svih oblika rasne diskriminacije (Narodne novine - Međunarodni ugovori broj 12/93.).

30. Ugovor o Europskoj uniji i Ugovor o funkcioniranju Europske unije, Pročišćene inačice, 2010/C 82/01.

31. Povelja o temeljnim pravima Europske unije, 2010/C 83/02. 
32. Europska konvencija za zaštitu ljudskih prava i temeljnih sloboda s pripadajućim protokolima (Narodne novine - Međunarodni ugovori broj 6/99. - pročišćeni tekst, 8/99., 14/02. i 9/05.).

33. Okvirna konvencija za zaštitu nacionalnih manjina (Narodne novine - Međunarodni ugovori, br. 14/1997.).

34. Ustav Republike Hrvatske (Narodne novine broj 85/10. - pročišćeni tekst).

35. Ustavni zakon o Ustavnom sudu Republike Hrvatske (Narodne novine broj 49/02. pročišćeni tekst).

36. Ustavni zakon o pravima nacionalnih manjina (Narodne novine broj 155/02., 47/10. - odluka USRH, 80/10. i 93/11. - odluka USRH).

37. Zakon o službenoj uporabi jezika i pisma nacionalnih manjina u Republici Hrvatskoj (Narodne novine broj 51/00. i 56/00. - ispravak).

38. Zakon o suzbijanju diskriminacije (Narodne novine broj 85/08. i 112/12.). 


\section{POSITIVE DISCRIMINATION IN THE REGULATION AND PROTECTION OF THE RIGHTS AND FREEDOMS OF NATIONAL MINORITIES - THE ROLE OF THE CONSTITUTIONAL COURT OF THE REPUBLIC OF CROATIA}

Implementing the banning of discrimination is one of the most important tasks of all bodies dealing with the protection of human rights and fundamental freedoms. That is, every achieved outlawing of discrimination is a firm indication of the violation of human rights and fundamental freedoms. However, from that important principle in legal political and overall social relations, there are also exceptions or deviations. They can be seen in the principle of positive discrimination which is a necessary corrective in achieving the rights and freedoms of minorities or underrepresented groups. That is, in democratic societies, where the principle of majority rules, reaching decisions on underrepresented groups, always depends on decisions which the majority reaches. Regardless of how 'democratic' society is, a democratic society with its principle of rule of law cannot allow the majority to freely assess whether it will decide on the legal regulation, achieving and protection of minority rights in order to allow achievement of this in all segments of social relations of important rights and freedoms for their self-actualisation. For this reason, countries with the rule of law, by legally regulating positive discrimination ensure legal constitutional guarantees so that minorities regulate, achieve and protect so called positive rights and freedoms which in turn ensure the self-actualisation of these rights through achieving their ethos. Positive discrimination is precisely therefore one of the most complex, but very sensitive legal, political issues in general. It is necessary. Although positive, it is discrimination, nonetheless. Its sensitivity is present regardless of the fundamentals which it prescribes. However, in relation to some of them, it can have, and most often does have, wider legal, political and even cultural implications. A striking example is the applied principle of positive discrimination among national minorities. Because this is a sensitive area, every positive discrimination, in order to be permitted and justified, must be necessary and needed in a democratic society. It must be objectively justified with a previously legally justified legitimate aim and it must be proportionate.

This paper attempts to conceptually determine according to the concepts of banning and positive discrimination and their mutual differences. The most important legal sources, according to the author, have been chosen and analysed. These regulate both national and transnational principles.

Particular attention has been paid to positive discrimination in the regulation, achieving and protection of the rights and freedoms of national minorities, all of course within the legal constitutional order of the Republic of Croatia.

Finally, constitutional court procedure and the decision making of the Constitutional Court of the Republic of Croatia is dealt with in the abstract and concrete controls of constitutionality and legality of positive discrimination in relation to national minorities. Stances taken by the Constitutional Court in proceedings in such cases have been supported by concrete examples.

Key words: human (and minority) rights, rights and fundamental freedoms, banning discrimination, positive discrimination, national minorities, constitutionality and legality, Constitutional Court of the Republic of Croatia 